\title{
RADIOCARBON DATING OF THE EARLY BRONZE AGE CEMETERY AT ARANO, VERONA, NORTHERN ITALY
}

\author{
Erio Valzolgher ${ }^{1} \cdot$ John Meadows $^{2} \cdot$ Paola Salzani $^{3} \cdot$ Luciano Salzani $^{4}$
}

ABSTRACT. Seventeen of the 73 individuals buried in the Early Bronze Age (EBA) cemetery at Arano di Cellore di Illasi, near Verona, northern Italy, were radiocarbon dated by accelerator mass spectrometry (AMS). Bayesian modeling of the calibrated dates suggests that the cemetery was probably used over several generations mainly within the first 2 centuries of the 2nd millennium cal BC. Burial activity was therefore mainly restricted to within the EBA I B/EBA I C of the north Italian Bronze Age chronology. An isolated burial, found $\sim 90 \mathrm{~m}$ northwest of the cemetery, may date to the same period.

\section{INTRODUCTION}

Arano di Cellore di Illasi (henceforth referred to as Arano) is located on the floor of the lower Illasi Valley, at the foot of the Lessini Mountains, $\sim 15 \mathrm{~km}$ northeast of Verona, northern Italy $\left(45^{\circ} 29^{\prime} 3^{\prime \prime} \mathrm{N}\right.$, $11^{\circ} 11^{\prime} 4^{\prime \prime} \mathrm{E} ; \sim 210 \mathrm{~m}$ asl; see Figure 1). Excavations undertaken at Arano in advance of development works between March and October 2007 by the Soprintendenza per i Beni Archeologici del Veneto, under the direction of Luciano Salzani, revealed the largest Early Bronze Age (henceforth EBA) flat inhumation cemetery known from northern Italy to date, and an earlier ceremonial structure; that is, a triangular level stone platform dating to the Copper Age (see Salzani and Salzani 2008).

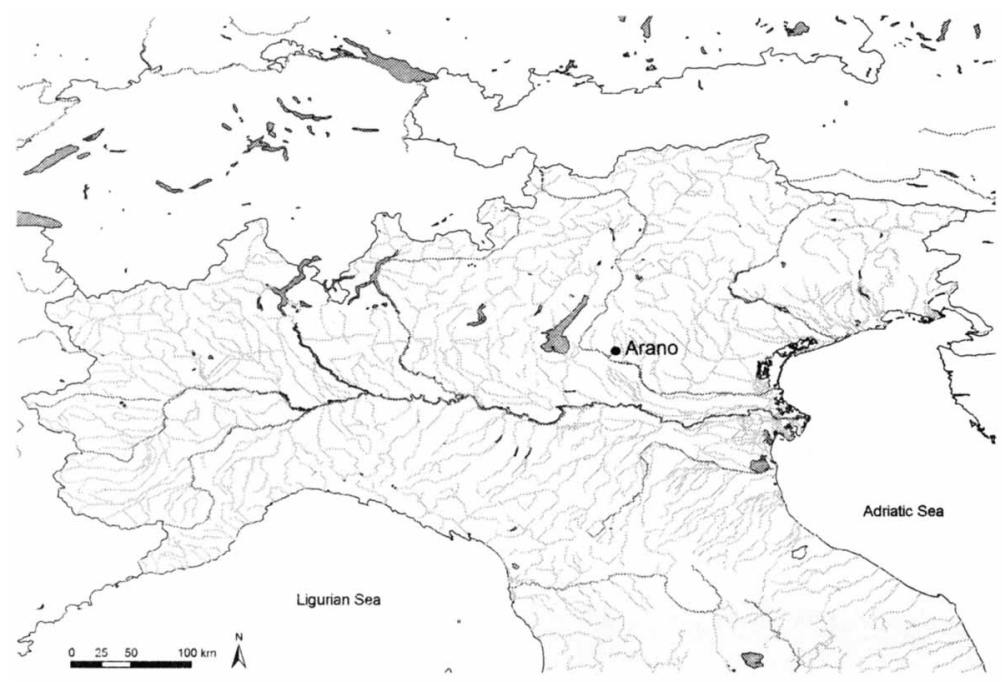

Figure 1 Map showing the location of the Arano site in northern Italy

\footnotetext{
' Ricerche Archeologiche snc/Archäologische Untersuchungen OHG, via Guglielmo Marconi/Guglielmo-Marconi-Strasse 8, I-39042 Bressanone/Brixen (Bolzano/Bozen), Italy. Corresponding author. Email: eriovalz@gmail.com.

2Zentrum für Baltische und Skandinavische Archäologie (ZBSA), Stiftung Schleswig-Holsteinische Landesmuseen Schloss Gottorf, Schlossinsel 1, D-24837 Schleswig, Germany; also: Leibniz-Labor für Altersbestimmung und Isotopenforschung, Christian-Albrechts-Universität zu Kiel, Max-Eyth-Strasse 11-13, D-24118 Kiel, Germany.

${ }^{3}$ Scuola di Dottorato in Studi Umanistici. Discipline Filosofiche, Storiche e dei Beni Culturali, Università degli Studi di Trento, via Tommaso Gar 14, I-38122 Trento, Italy.

${ }^{4}$ Formerly Soprintendenza per i Beni Archeologici del Veneto - Nucleo Operativo di Verona, Piazza San Fermo 3, I-37121 Verona, Italy.
} 
The Arano cemetery, covering a $\sim 1750-\mathrm{m}^{2}$ area (labeled Settore $B$ ), yielded 68 burial structures (see Figure 2). Of these, 61 were inhumation graves, 6 did not produce human remains, and can thus be tentatively classified as cenotaphs (G 20, G 31, G 33, G 37, G 47, and G 65), while 1 contained burned bones, which have not yet been analyzed (G 22). Among the 61 inhumation graves, there were 53 single burials, 4 double burials (G 6, G 16, G 30, and G 55), and 4 triple burials (G 3, G 4, G 9, and G 19). Altogether, 73 skeletons, mostly in a poor state of preservation, were recovered from the cemetery. These were buried in a contracted/hypercontracted posture, with flexed legs and arms, lying either on their left side with the head to the south, or on their right side with the head to the north, but in all cases facing west-except for the skeletons from G 43 and G 60, lying on their right side with the head to the south facing east. Although the anthropological analyses have not yet been completed, ${ }^{5}$ and great caution is thus required, the available data would seem to indicate that at Arano these 2 distinct types of positioning might tendentially be sex-dependent (specifically, leftcrouched males and right-crouched females, with the head in opposite directions).

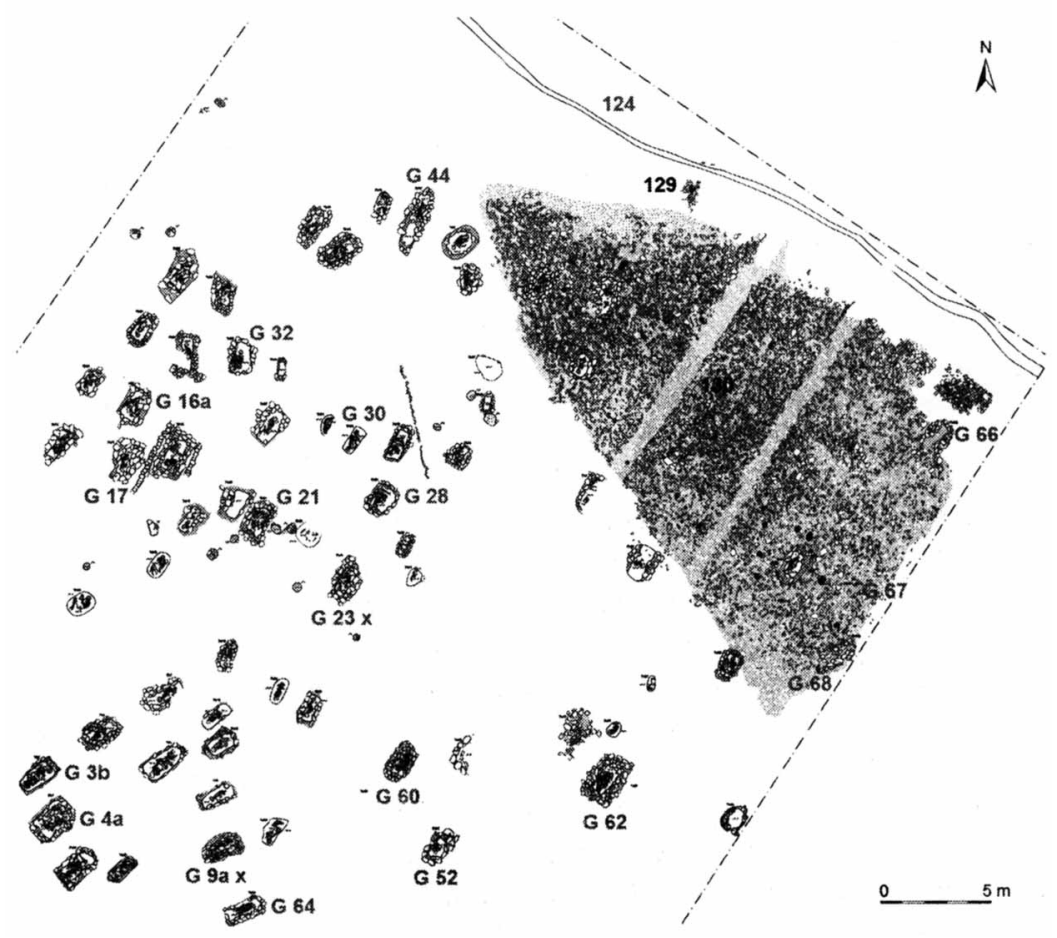

Figure 2 Plan of the Arano EBA cemetery indicating the ${ }^{14} \mathrm{C}$-dated graves (in bold red type). Graves for which dating failed due to insufficient collagen yield are marked with the letter $x$. Key: 124 (bold red type), a ditch bounding the cemetery area to the northeast; 129 (bold black type), a Copper Age pit; and 130 (bold black type), a Copper Age ceremonial platform (drawing by Jim Manning-Press [SAP Società Archeologica srl] and Paola Salzani. (C) Soprintendenza per i Beni Archeologici del Veneto).

\footnotetext{
${ }^{5}$ The anthropological analyses - undertaken by Jacopo Moggi Cecchi and collaborators at the Dipartimento di Biologia Evoluzionistica "Leo Pardi," Università degli Studi di Firenze, Italy - are still underway. Owing to their fragmentary condition, the human remains have had to undergo a long and demanding restoration process in advance of the anthropological analyses. Age and sex have therefore been estimated for a limited number of skeletons so far (as of December $2011,43.8 \%$ of the total [J Moggi Cecchi, personal communication, 2011]).
} 
Such a "sexually differentiated bipolar deposition mode" (Harding 2000:77) has been well documented, e.g. in EBA flat inhumation cemeteries north of the Alps (e.g. Singen am Hohentwiel in Baden-Württemberg, SW Germany [Krause 1988]; Gemeinlebarn F and Franzhausen I in Lower Austria [Neugebauer 1991; Neugebauer and Neugebauer 1997]). A similar, close relationship between positioning of the body in the grave and biological sex has been suggested by de Marinis (2003:43, 46-7) for the north Italian EBA flat inhumation cemeteries at Sorbara di Asola (Mantua) and Valserà di Gazzo Veronese (Verona). In the former, as at Arano, individuals $(n=19)$ were buried crouched either on their left side with the head to the south, or on their right side with the head to the north, in all cases facing west (Baioni 2000:49, 78, Table 1, 2005:201); in the latter, individuals ( $n=$ 11) were either left-crouched or right-crouched, too, but with the head placed following a much looser, erratic orientation pattern (see Salzani 2001:76, Figure 1). According to de Marinis (2003:43, 46-7), at both cemeteries the position on the left side would have been restricted to males, while the position on the right side to females. ${ }^{6}$ In a very few cases, the Arano skeletons, though with flexed legs, were not buried with the torso resting on one side, but in either a supine or prone position.

A further, isolated child inhumation burial (G US 20-1a), covered with stones and likely by a wooden structure as well, was identified $\sim 90$ m northwest of the cemetery, in close proximity to a settlement area (labeled Settore A). However, as the analysis of this context is still at a preliminary stage, the relationship between G US 20-1a and the settlement area has not yet been fully clarified.

As for the architectural typology of the (trench) burials at Arano, a certain degree of variability can be observed. In some cases, the trench walls were lined with stones (cobbles or boulders) and the grave was subsequently covered with stones. Other graves were stone-lined, but not stone-covered, or were stone-covered, but not stone-lined. It seems likely that the stone coverings were originally supported by wooden planks. In a few instances, the graves were simple trenches, neither stonelined nor stone-covered. No cases of intercutting graves have been recorded.

Overall, grave goods were recovered from only 13 graves ( 7 single graves [G 18, G 21, G 27, G 32, G 49, G 53, and G 60], 2 double graves [ $G 6$ and $G$ 16], and 4 triple graves [G 3, G 4, G 9, and $G$ 19]). Nonetheless, some empty areas within a number of graves would seem to hint at the original deposition of grave goods made of perishable materials. Grave goods mainly consist of personal ornaments, including stone and marine shell (Dentalium sp.) necklace elements (see e.g. Figure 5.2, 5.5-6), and pendants made of bone and stone (see e.g. Figure 5.3). Ornaments also encompass a few metal items - an Ösenhalsring-type neckring from the adult female burial G 60 (Figure 4.1) and a bracelet from $\mathrm{G} 49$ (Figure 5.4). Only 1 burial (G 21), that of a young adult male, was accompanied by a weapon-a round-heeled riveted metal dagger (Figure 4.2). (The chemical composition of the high-status metal artifacts associated with G 21 and G 60 is discussed below.) Pottery occurs just in 1 burial (G 19) (Figure 5.1). It is uncertain whether a barbed and tanged flint arrowhead found in G 7 represents a grave good or whether its presence in the grave was coincidental.

All graves had originally been dug in Layer 103, an alluvial deposit made up of fine-grained sediments with occasional gravel lenses. This alluvial deposit, which thus preceded the use of the area as a burial place in the EBA, sealed a Copper Age ceremonial feature, namely the triangular stone platform mentioned above (Platform 130; see Figure 2). (Previously, 3 graves [G 66, G 67, and

\footnotetext{
${ }^{6}$ It should be stressed, however, that for Sorbara di Asola, due to the lamentable lack of published anthropological data, such a burial practice has been postulated based solely on the grave-good types, while for Valserà di Gazzo Veronese, based on anthropological data (which, though, were obtained for just 5 of the 11 individuals buried in this cemetery [i.e. G 10, G 11 , G 15, G 17, and G 18; see Drusini and Carrara 1998-1999]).
} 
G 68] were thought to be closely associated with the use of Platform 130 [see Salzani and Salzani 2008:18]. Based on a thorough stratigraphic reassessment of this context, as well as on the ${ }^{14} \mathrm{C}$ results obtained for these 3 graves [see below], such an association can now be excluded.)

Given its degree of deterioration, it seems likely that Platform 130-aligned NW-SE and covering a $\sim 225-\mathrm{m}^{2}$ area-had long been exposed to the elements after its abandonment and prior to the alluviation episode(s) represented by Layer 103. However, a deliberate spoliation of the original stone structure cannot be ruled out. No absolute dates are yet available for Platform 130, so we cannot precisely estimate its date of construction or the overall time period it was in use. Nevertheless, some diagnostic pottery finds directly associated with the ceremonial structure-in particular, an undecorated carinated bowl with vertically perforated lugs (Figure 3.1), bearing a striking resemblance to ceramic vessels from the north Italian Copper Age cemeteries at Remedello Sotto (Brescia) and Manerba del Garda-Riparo Valtenesi (Brescia) ${ }^{7}$ - clearly point to the use of Platform 130 at least within the first half of the 3rd millennium cal BC (for the absolute chronologies of the cemeteries at Remedello Sotto and Manerba del Garda-Riparo Valtenesi, see de Marinis 1997 and Barfield et al. 2010, respectively). Such a chronological assignment would not seem to be contradicted by the scale-decorated ware (ceramica a squame) sherd (Figure 3.3) recovered, along with a polished greenstone axehead and worked flint, from a shallow pit (129) adjacent to Platform 130 (the scaledecorated ware being attested throughout the second half of the 4th and the first half of the 3rd millennia cal BC; see e.g. Ferrari and Steffè 2009:190; Bernabò Brea et al. 2010:16-7 [unnumbered table]; Cocchi Genick, forthcoming). We cannot exclude that Platform 130 was in use even after the first half of the 3rd millennium cal $\mathrm{BC}$, but it should be pointed out that no finds unambiguously dating to the late Copper Age ( $2500-2200 \mathrm{cal} \mathrm{BC})$ were recovered from it (contrary to previous suggestions [see Salzani and Salzani 2008:18]).

\section{THE ARANO ${ }^{14} \mathrm{C}$ DATING PROGRAM}

\section{Aims}

The Arano ${ }^{14} \mathrm{C}$ dating program was primarily designed to attain an accurate absolute chronology for the cemetery, and indeed to determine its precise placement in the framework of the EBA $(\sim 2200$ 1600 cal BC - according to the north Italian Bronze Age chronology established by de Marinis [1999]; see also de Marinis et al., forthcoming), both on a regional and on a broader, super-regional scale. In this regard, it is worth noting that no ${ }^{14} \mathrm{C}$ dates have yet been obtained for 2 of the most important EBA burial complexes currently known from northern Italy; that is, the small-sized flat inhumation cemeteries, already mentioned, excavated in the late 1990s/early 2000s at Sorbara di Asola (Mantua) (Baioni 2000, 2005; de Marinis 2003:42-50; Nicolis 2004:115-6) and Valserà di Gazzo Veronese (Verona) (Salzani 1998-1999, 2001; Nicolis 2002, 2004:113-5; de Marinis 2003: $46-7,50) .{ }^{8}$ Their dating thus still relies entirely on typological attributions.

The Arano ${ }^{14} \mathrm{C}$ dating program had the following objectives: 1) to determine, using Bayesian statistical analysis, the start, the end, and the overall chronological span of the burial activity at the site;

\footnotetext{
${ }^{7}$ For Remedello Sotto, see Cornaggia Castiglioni 1971:54-5, Plate XIV:2; Longhi 2010:154, Figure 4 (BS IV), 157-8, 163, Figure 6.4 (carinated bowl with vertically perforated lugs and metope decoration from G BS IV). For Manerba del GardaRiparo Valtenesi, see Barfield 1999:56, 62, Figure 2.6, 2007:164, 178, Figure 108 (P77), 203 (carinated bowl with a vertically perforated lug and dragged comb [a pettine trascinato] decoration associated with the Burnt Burial Deposit N1-N3).

${ }^{8}$ In mid-1999, an attempt was made at the RJ Van de Graaff Laboratorium (Faculteit Natuur- en Sterrenkunde, Universiteit Utrecht, the Netherlands) to AMS date 1 adult male inhumation (G 10) from Valserà di Gazzo Veronese, but the attempt failed because there was no collagen yield (Salzani 1998-1999:65; K van der Borg, personal communication, 2012).
} 

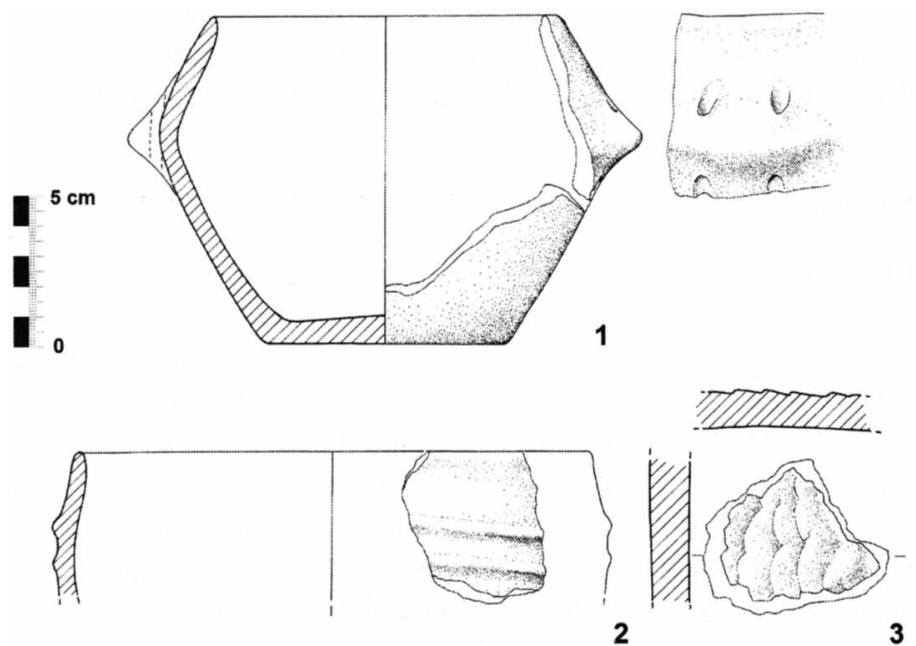

Figure 3 Selected Copper Age pottery from Arano: 1) carinated bowl with vertically perforated lugs from Platform 130;2) cordoned pot from Platform 130;3) scale-decorated ware (ceramica a squame) sherd from Pit 129 (drawings by Raffaella Giacometti. (C) Soprintendenza per i Beni Archeologici del Veneto).
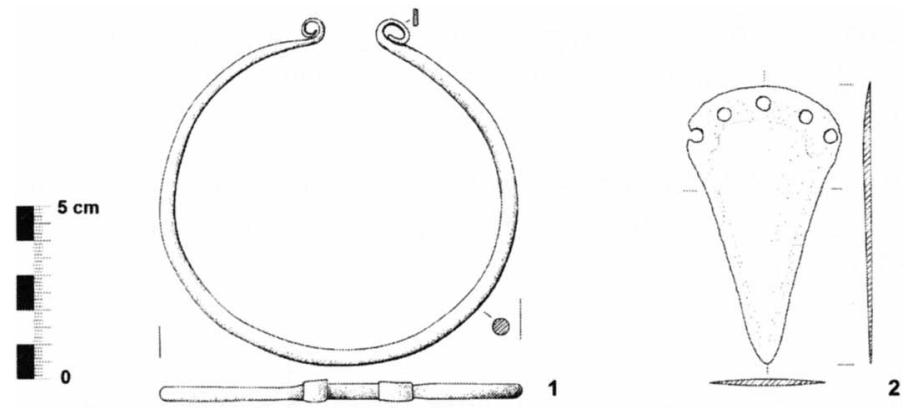

Figure 4 Metal artifacts from the Arano cemetery: 1) Ösenhalsring-type neckring from $\mathrm{G} 60 ; 2$ ) round-heeled riveted dagger from $\mathrm{G} 21$ (drawings by Raffaella Giacometti. (C) Soprintendenza per i Beni Archeologici del Veneto).

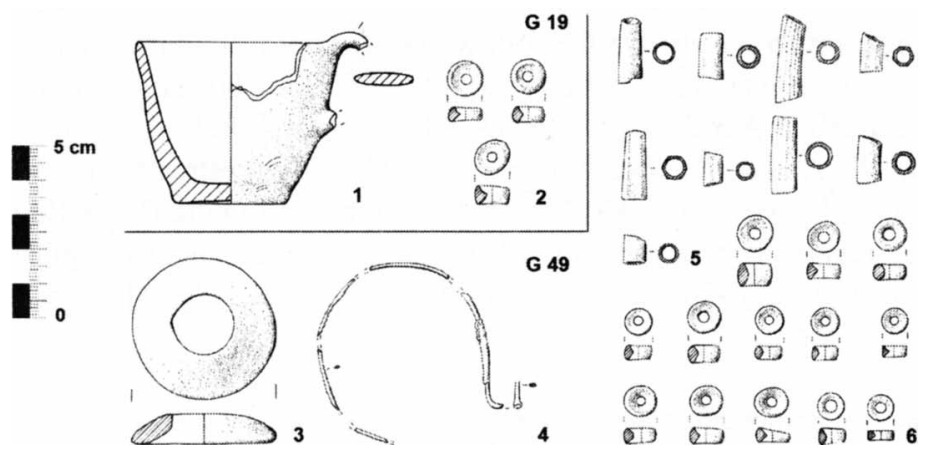

Figure 5 Selected grave goods from the Arano cemetery. G 19:1) miniature pot; 2) stone beads (probably calcite). G 49: 3) stone pendant (probably limestone); 4) metal bracelet; 5) Dentalium sp. shell beads; 6) stone beads (probably calcite) (drawings by Raffaella Giacometti. (C) Soprintendenza per i Beni Archeologici del Veneto). 
2) to test whether different areas of the cemetery were used in different time periods; and 3) to answer questions concerning the absolute chronology of the metal artifacts found at the cemetery (specifically, the dagger from G 21 and the neckring from G 60), with respect to their peculiar chemical composition.

\section{Materials and Methods}

Between early 2008 and late 2010, 19 human bone samples - taken from 19 distinct skeletons (G 3b, G 4a, G 9a, G 16a, G 17, G 21, G 23, G 28, G 30, G 32, G 40, G 44, G 52, G 60, G 62, G 64, G 66, G 67, and G 68) - were submitted for accelerator mass spectrometry (AMS) ${ }^{14} \mathrm{C}$ measurement to the Centro di Datazione e Diagnostica (CEDAD), Dipartimento di Ingegneria dell'Innovazione, Università del Salento, Lecce (Italy) (see Table 1). The generally poor state of preservation of the human skeletal material restricted the sampling of elements such as long bones; in almost all cases, bones of the hand (metacarpals) and of the foot (metatarsals) were selected because larger bones had already been restored and consolidated with Paraloid ${ }^{\mathrm{TM}}$ B-72 and/or Primal ${ }^{\mathrm{TM}}$ AC-33. ${ }^{9}$ The only exceptions were the long bone fragment from G 16a and the rib fragments sampled from G 66 and G 67, which had specifically been set aside for dating purposes and had not been consolidated (see Table 1). All the bone samples dated were from single bones, with the exception of G 17 and G 30 , of which 3 and 2 bones respectively were dated; in both cases, however, it is certain that the bones sampled were from a single individual (see Table 1).

In addition to the human bone samples from the Settore $B$ cemetery, a charcoal fragment (almost certainly of deciduous oak [Quercus sp. section $R O B U R])^{10}$ from the wooden structure that likely originally covered the child inhumation burial (G US 20-1a) found in Settore A (see above) was AMS dated at the same laboratory in early 2008 (see Table 3 ).

Samples were pretreated and AMS dated at CEDAD as described by D'Elia et al. (2004), Quarta et al. (2004), and Calcagnile et al. (2005). Two measurements on human bone (from G 9a and G 23) failed due to insufficient yield.

\section{Results}

Seventeen skeletons (23.2\% of the individuals buried in the Arano Settore B cemetery) were dated directly, one of them twice (G 67). The CEDAD result for the child burial G 67 (LTL-2897A) appeared to be significantly more recent than those obtained from the other inhumations dated at the same time, whose results were fairly tightly clustered (see Table 1). As the G 67 sample was taken from one of the child's ribs, it was suspected that the thin cortical bone may have been heavily contaminated by younger organic matter in the soil, which was not fully removed during pretreatment. A second sample was therefore taken from one of the child's long bones, and submitted in late 2010 to the Oxford Radiocarbon Accelerator Unit (ORAU), Research Laboratory for Archaeology and the History of Art (RLAHA), University of Oxford (UK), for pretreatment by ultrafiltration, as described by Brock et al. (2010), and AMS ${ }^{14} \mathrm{C}$ measurement following Bronk Ramsey et al. (2004) (see Table 2). The 2 results for the child burial G 67 are statistically inconsistent, according to Ward and Wilson's (1978) test (LTL-2897A and OxA-24137: T' $=9.5 ; \mathrm{T}^{\prime}[5 \%]=3.8 ; \mathrm{v}=1$ ), and these

\footnotetext{
${ }^{9} \mathrm{At}$ the time of sampling, the following skeletons selected for ${ }^{14} \mathrm{C}$ dating had already been consolidated (both in the field and in the laboratory): G 16a, G 17, G 21, G 23, G 28, G 32, G 64, G 66, G 67, and G 68 (J Moggi Cecchi, personal communication, 2009).

${ }^{10} \mathrm{M}$ Marchesini, personal communication, 2010. (Note: Quercus sp. section ROBUR, as defined by Cambini [1967a,b], includes the following 3 species: Quercus robur L., Quercus petraea [Matt.] Liebl., and Quercus pubescens Willd.)
} 


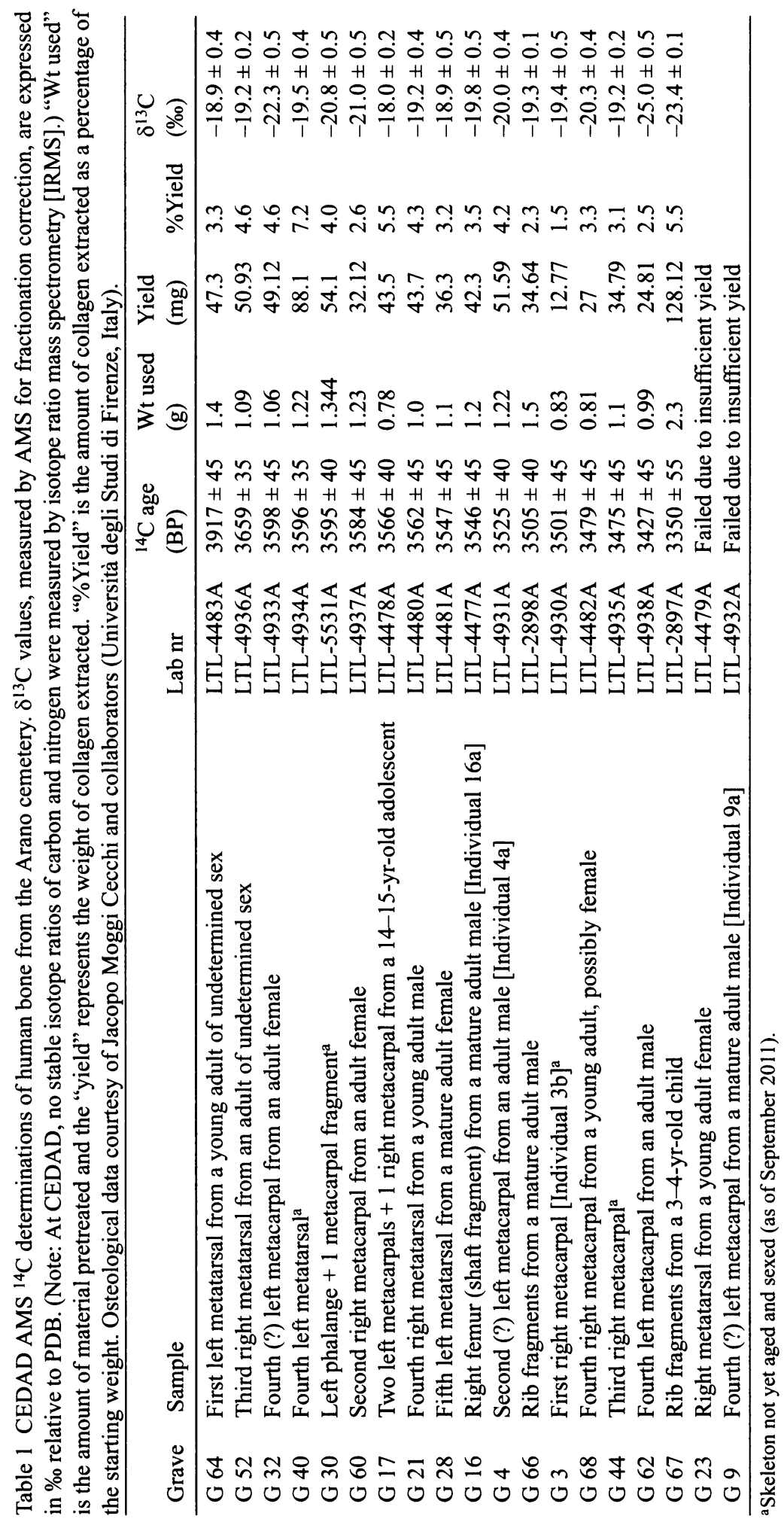


results cannot both be accurate. The fact that LTL-2897A was from a rib sample, and that this result is more recent than OxA-24137 (from a long bone), as well as the results on metacarpals and metatarsals from other burials at Arano, strongly suggests that contamination from the burial environment was not fully removed from the rib, and that LTL-2897A should be rejected.

Tables $1-3$ give all the ${ }^{14} \mathrm{C}$ results and additional laboratory data. When calibrated (Table 4 ), all the samples were dated to the later 3rd-earlier 2nd millennium cal BC. The maturity of the charcoal fragment from the child inhumation burial in Settore A (G US 20-1a) was not recorded, and it is therefore possible that its calibrated result (LTL-2899A; Table 4) is subject to a significant woodage offset. ${ }^{11}$ The results fall in the EBA, as expected (see Salzani and Salzani 2008). The only exception is LTL-4483A (G 64): after calibration, this result dates to the late Copper Age (2570$2230 \mathrm{cal}$ BC, $95 \%$ confidence), a period not represented in the cemetery by diagnostic artifacts. The grave itself is of the same type as the majority of those ${ }^{14} \mathrm{C}$ dated to the EBA (G 3, G 16, G 17, G 21, G 28, G 32, G 40, G 44, G 52, G 60, and G 62); that is, a stone-lined and stone-covered trench grave. The unaccompanied skeleton (that of a young adult of undetermined sex lying crouched on his/her right side, with the head to the north facing west, as e.g. the skeletons from $\mathrm{G} 40$ and $\mathrm{G} 67,{ }^{14} \mathrm{C}$ dated to the EBA) was found in articulation, and it therefore seems implausible that the sample dated was residual (i.e. older than the grave it was found in). Although it cannot be excluded that the calibration of LTL-4483A accurately dates the G 64 burial, a dietary reservoir effect could also account for the unexpectedly early result. Another plausible explanation for what appears to be an anomalously early date for G 64 is that the bone sampled had, after all, been contaminated by Paraloid B-72 and/ or Primal AC-33, notwithstanding the care taken to select only elements that had not been consolidated. ${ }^{12}$ In interpreting the ${ }^{14} \mathrm{C}$ results, therefore, we have considered all these possibilities.

Table 2 ORAU AMS ${ }^{14} \mathrm{C}$ determination of human bone from $\mathrm{G} 67$. Stable isotope ratios of carbon and nitrogen, measured by isotope ratio mass spectrometry (IRMS), are expressed in \%o relative to VPDB (Coplen 1994) and AIR (Mariotti 1983), respectively. Mass spectrometric precision is $\pm 0.2 \%$ for carbon and $\pm 0.1 \%$ for nitrogen. "Wt used" is the amount of material pretreated and the "yield" represents the weight of ultrafiltered collagen. "\%Yield" is the amount of collagen extracted as a percentage of the starting weight, which ideally should not be $<1 \mathrm{wt} \%$ at ORAU. "\%C" is the carbon present in the collagen on combustion. "CN" is the atomic ratio of carbon to nitrogen. At ORAU, this is considered acceptable if it ranges between 2.9 and 3.5 (van Klinken 1999). Osteological data courtesy of Jacopo Moggi Cecchi and collaborators (Università degli Studi di Firenze, Italy).

\begin{tabular}{lllllllllll}
\hline Grave & Sample & Lab nr & $\begin{array}{l}{ }^{14} \mathrm{C} \text { age } \\
(\mathrm{BP})\end{array}$ & $\begin{array}{l}\text { Wt used } \\
(\mathrm{mg})\end{array}$ & $\begin{array}{l}\text { Yield } \\
(\mathrm{mg})\end{array}$ & $\%$ Yield & $\% \mathrm{C}$ & $\delta^{13} \mathrm{C}$ & $\delta^{15} \mathrm{~N}$ & $\mathrm{CN}$ \\
\hline G 67 & $\begin{array}{l}\text { Right tibia or fibula } \\
\text { fragment from a } \\
\text { 3-4-yr-old child }\end{array}$ & OxA-24137 & $3542 \pm 28$ & 150 & 7.84 & 5.2 & 50.3 & -21.7 & 11.7 & 3.5 \\
\hline
\end{tabular}

\footnotetext{
${ }^{11}$ Following osteological recording, a sample of the right humerus of the 3-4-yr-old child in G US 20-1a was submitted to ORAU to refine the dating of this isolated burial. The result was not available when this manuscript was revised (July 2012). ${ }^{12}$ D'Elia et al. (2007) found that - following the same standard pretreatment protocol used for LTL-4483A-collagen from a bone deliberately contaminated with Paraloid B-72 gave an acceptable ${ }^{14} \mathrm{C}$ age. However, as stated by D'Elia et al. (2004), at CEDAD samples known to have been contaminated by conservation agents would have usually been pretreated with solvents in a Soxhlet apparatus to remove contamination (Bruhn et al. 2001), before demineralization and gelatinization following the Longin method (Longin 1971), modified by Quarta et al. (2004).
} 
Table 3 CEDAD AMS ${ }^{14} \mathrm{C}$ determination of charcoal from G US 20-1a. $\delta^{13} \mathrm{C}$, measured by AMS for fractionation correction, is expressed in \%o relative to PDB. Anthracological data courtesy of Marco Marchesini (Università degli Studi di Ferrara, Italy).

\begin{tabular}{lllll}
\hline Grave & Sample & \multicolumn{3}{c}{${ }^{14} \mathrm{C}$ age } \\
G US 20-1a & $\begin{array}{l}\text { Charcoal fragment from a charred wooden plank } \\
\text { (likely deciduous oak [Quercus sp. section ROBUR]) }\end{array}$ & LTL-2899A & $3671 \pm 50$ & $-24.2 \pm 0.2$ \\
\hline
\end{tabular}

Table 4 Calibration of ${ }^{14} \mathrm{C}$ results. The $95 \%$ confidence intervals were calculated using the maximum intercept method of Stuiver and Reimer (1986), the calibration data of Reimer et al. (2009), and the program OxCal v 4.1 (Bronk Ramsey 2009a). The 95\% probability ranges were obtained from the posterior density estimates given by the model shown in Figure 7. In both cases, ranges have been rounded outward to decadal endpoints.

\begin{tabular}{|c|c|c|c|c|}
\hline Grave & Lab nr & $\begin{array}{l}{ }^{14} \mathrm{C} \text { age } \\
(\mathrm{BP})\end{array}$ & $\begin{array}{l}\text { Calibrated date range } \\
(95 \% \text { confidence })\end{array}$ & $\begin{array}{l}\text { Posterior density estimate } \\
(95 \% \text { probability; Figure } 7)\end{array}$ \\
\hline G 64 & LTL-4483A & $3917 \pm 45$ & $2570-2230 \mathrm{cal} \mathrm{BC}$ & $2570-2230 \mathrm{cal} \mathrm{BC}$ \\
\hline G 52 & LTL-4936A & $3659 \pm 35$ & $2140-1930 \mathrm{cal} \mathrm{BC}$ & $2010-1880 \mathrm{cal} \mathrm{BC}$ \\
\hline G 32 & LTL-4933A & $3598 \pm 45$ & $2130-1780 \mathrm{cal} \mathrm{BC}$ & $2010-1820 \mathrm{cal} \mathrm{BC}$ \\
\hline G 40 & LTL-4934A & $3596 \pm 35$ & $2040-1880 \mathrm{cal} \mathrm{BC}$ & $2010-1870 \mathrm{cal} \mathrm{BC}$ \\
\hline G 30 & LTL-5531A & $3595 \pm 40$ & $2120-1820 \mathrm{cal} \mathrm{BC}$ & $2010-1830 \mathrm{cal} \mathrm{BC}$ \\
\hline G 60 & LTL-4937A & $3584 \pm 45$ & $2120-1770 \mathrm{cal} \mathrm{BC}$ & $2010-1810 \mathrm{cal} \mathrm{BC}$ \\
\hline G 17 & LTL-4478A & $3566 \pm 40$ & $2030-1770 \mathrm{cal} \mathrm{BC}$ & $1980-1780 \mathrm{cal} \mathrm{BC}$ \\
\hline G 21 & LTL-4480A & $3562 \pm 45$ & $2030-1750 \mathrm{cal} \mathrm{BC}$ & $1980-1780 \mathrm{cal} \mathrm{BC}$ \\
\hline G 28 & LTL-4481A & $3547 \pm 45$ & $2030-1740$ cal BC & $1970-1780 \mathrm{cal} \mathrm{BC}$ \\
\hline G 16a & LTL-4477A & $3546 \pm 45$ & $2030-1740$ cal BC & $1970-1780 \mathrm{cal} \mathrm{BC}$ \\
\hline G 4a & LTL-4931A & $3525 \pm 40$ & $1960-1740 \mathrm{cal} \mathrm{BC}$ & $1950-1780 \mathrm{cal} \mathrm{BC}$ \\
\hline G 66 & LTL-2898A & $3505 \pm 40$ & $1950-1690 \mathrm{cal} \mathrm{BC}$ & $1940-1780 \mathrm{cal} \mathrm{BC}$ \\
\hline G 3b & LTL-4930A & $3501 \pm 45$ & $1950-1690 \mathrm{cal} \mathrm{BC}$ & $1950-1770 \mathrm{cal} \mathrm{BC}$ \\
\hline G 68 & LTL-4482A & $3479 \pm 45$ & $1930-1680 \mathrm{cal} \mathrm{BC}$ & $1940-1770 \mathrm{cal} \mathrm{BC}$ \\
\hline G 44 & LTL-4935A & $3475 \pm 45$ & $1920-1680 \mathrm{cal} \mathrm{BC}$ & $1930-1770 \mathrm{cal} \mathrm{BC}$ \\
\hline G 62 & LTL-4938A & $3427 \pm 45$ & $1890-1620 \mathrm{cal} \mathrm{BC}$ & $1920-1750$ cal $B C$ \\
\hline G 67 & OxA-24137 & $3542 \pm 28$ & $1960-1770 \mathrm{cal} \mathrm{BC}$ & $1950-1780 \mathrm{cal} \mathrm{BC}$ \\
\hline G US 20-1a & LTL-2899A & $3671 \pm 50$ & $2210-1910 \mathrm{cal} \mathrm{BC}$ & $2200-1920 \mathrm{cal} \mathrm{BC}^{\mathrm{a}}$ \\
\hline
\end{tabular}

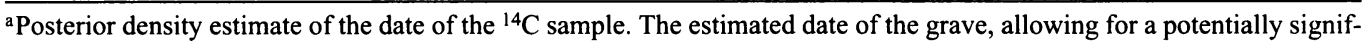
icant wood-age offset, is $2000-1790$ cal BC [95\% probability; Figure 7: $L T L-2899 A+U(0,300)]$.

\section{BAYESIAN CHRONOLOGICAL MODELING}

Bayesian chronological models allow us to combine sets of ${ }^{14} \mathrm{C}$ results with archaeological information about the relative dates of samples, and produce posterior density estimates of the dates of events of interest (Buck et al. 1996). These estimates are conventionally given in italics, to emphasize that they depend on all the information included in the model, and would change if, for example, another sample was dated.

It is essential to account for the inevitable statistical scatter in ${ }^{14} \mathrm{C}$ measurements when considering the timespan represented by a set of calibrated ${ }^{14} \mathrm{C}$ results. The "bounded phase" model in OxCal (Bronk Ramsey 1995, 2000, 2009a) is now widely used (see e.g. Maniatis and Ziota 2011), and in its basic form it assumes that the dated events are evenly distributed over time, between the start and end of the phase of activity with which these samples are associated. Testing has shown that this simple model provides realistic estimates of the start and end of a phase, unless the distribution of dated events is heavily skewed (Bayliss et al. 2007). Several variants of the "bounded phase" model have been developed to better deal with situations in which the temporal distribution of dated events is thought to be non-uniform (Bronk Ramsey 2009a). 
At Arano, the common burial rite, the recurring structural forms, and the relatively regular alignment and spacing of the Settore $B$ graves imply that this cemetery was the product of a single, continuous phase of burial activity, and that the basic "bounded phase" model is therefore appropriate in this case. Grave typology suggests that the single dated Settore A burial (G US 20-1a) might also be attributed to this phase. A "bounded phase" model can also incorporate dating constraints provided by stratigraphic information - for example, a burial sequence indicated by 1 grave cutting another, but at Arano the graves do not intercut (itself an indication that the cemetery may have had a relatively short period of use), and there is no other archaeological evidence that would clarify the burial sequence.

Our initial model includes all $18{ }^{14} \mathrm{C}$ results (omitting LTL-2897A, which we have rejected) within a "bounded phase" (Figure 6). The date of the charcoal sample from Settore A (LTL-2899A) might be regarded merely as a terminus post quem for burial G US 20-1a, but as the charcoal is thought to have been from a plank (M Marchesini, personal communication, 2011) from the ceiling of this grave, the felling date of the timber concerned should be directly relevant to the date of the burial. If this was a plank, however, it is likely to have come from a mature tree, and the wood-age offset for LTL-2899A (almost certainly oak) is potentially high. A prior uniform probability distribution of 0-300 yr was therefore selected for the wood-age offset. Such a broad prior distribution effectively means that LTL-2899A does not affect the model's estimated dates of the other graves.

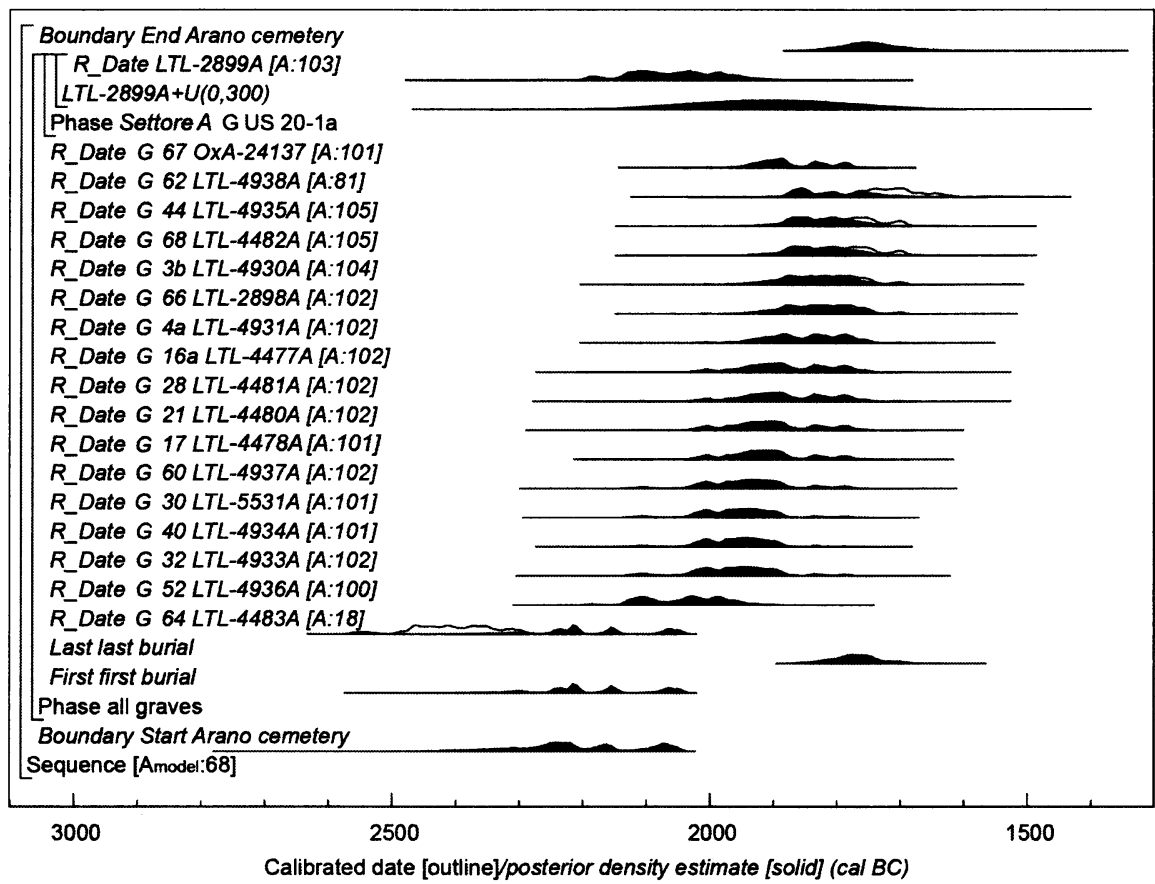

Figure 6 The basic "bounded phase" model of ${ }^{14} \mathrm{C}$ results from Arano. The brackets and OxCal "verbs" (Bronk Ramsey 2009a) at the left margin define the model structure precisely. Distributions in outline are the calibrations of each ${ }^{14} \mathrm{C}$ result, using the probability method of Stuiver and Reimer (1993) and the calibration data of Reimer et al. (2009). Solid distributions are the model's posterior density estimates of the dates of these samples and of associated events. The very poor individual index of agreement $(A<<6)$ indicates a serious discrepancy between the 2 distributions for LTL-4483A, suggesting that this result does not belong in the "bounded phase." 
The initial model gives satisfactory "dynamic agreement" $\left(\mathrm{A}_{\text {model }}>60\right.$; Bronk Ramsey $\left.2009 \mathrm{a}\right)$, which indicates that the calibrated ${ }^{14} \mathrm{C}$ results do not contradict the assumption that the samples represent a single, continuous phase of burial activity. The individual indices of agreement are also satisfactory ( $\mathrm{A}>60$; Bronk Ramsey 1995), aside from that for LTL-4483A $(\mathrm{A}=18)$, which is low enough to suggest that $\mathrm{G} 64$ might not belong in this phase after all. Indeed, if the model omits this result (Figure 7), the estimated probability that LTL-4483A belongs in the resulting phase of activity is negligible ( $p=0$; Bronk Ramsey 1995). Omitting LTL-4483A, however, has a profound effect on the posterior density estimates (compare Figures 6 and 7), and we have therefore tried to consider any other realistic interpretations before removing this result from the model.

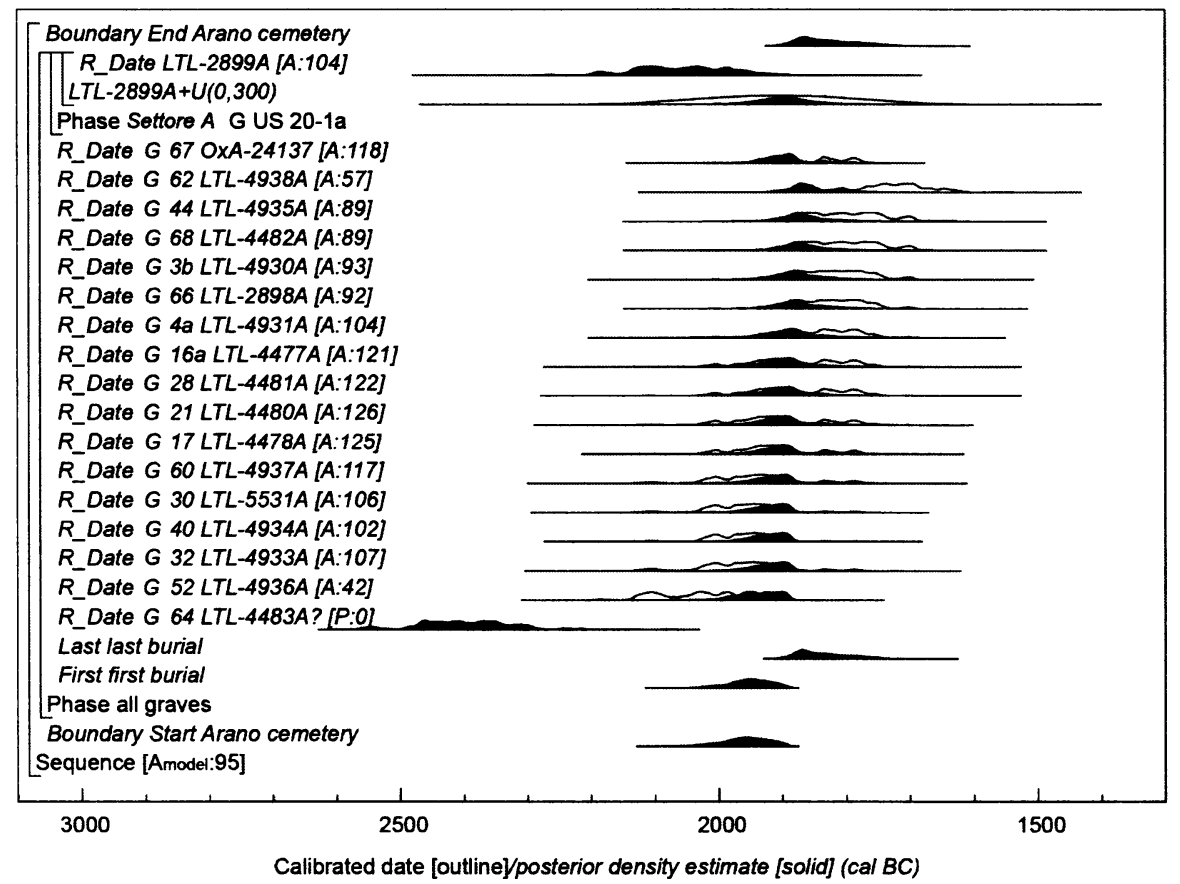

Figure 7 The basic model of ${ }^{14} \mathrm{C}$ results from Arano, with LTL-4483A excluded from the "bounded phase." The format is identical to that of Figure 6.

One possibility is that LTL-4483A is not misleading, but the temporal distribution of the dated events (burials) may be heavily skewed -in other words, perhaps the intensity of burial activity (the frequency of burials) increased dramatically over time, as the population grew or the mortality rate increased (see e.g. Maniatis and Ziota 2011). In this case, the start of burial activity might be better estimated using one of the alternative Boundary functions available in OxCal $\mathrm{v} 4.1$, Zero_Boundary, Tau_Boundary, or Sigma_Boundary, in place of Boundary Start Arano cemetery in the model shown in Figure 6. The use of Zero_Boundary would imply a steady (linear) increase in the frequency of burials over time; Tau_Boundary assumes an exponential increase in the frequency of dated events; and Sigma Boundary assumes that the dated events are normally distributed in time (Bronk Ramsey 2009a). We have no archaeological evidence that would allow us to choose which, if any, of these variants is most appropriate. Only in the first case does the model's posterior density estimate for the initial boundary correspond to the actual beginning of the phase of activity (Bronk Ramsey 2009a:346, Figure 4), so we have used the First 
function to generate a probability distribution for the first burial under each variant, as well as in the initial models (Figures 6-7).

Details of the variant models' output are shown in Figure 8. The variant models all have good "dynamic agreement" ( $\left.\mathrm{A}_{\text {model }}>60\right)$, all produce much better individual agreement for LTL-4483A $(\mathrm{A}>50)$, and their estimates of the date of the first burial, and of the duration and end of burial activity are all similar. ${ }^{13}$ In each case, however, the posterior density estimates depend to a high degree on the inclusion or omission of LTL-4483A. Thus, the choice of which "bounded phase" model is most appropriate at Arano is far less significant than the choice of which results to include in the "bounded phase."

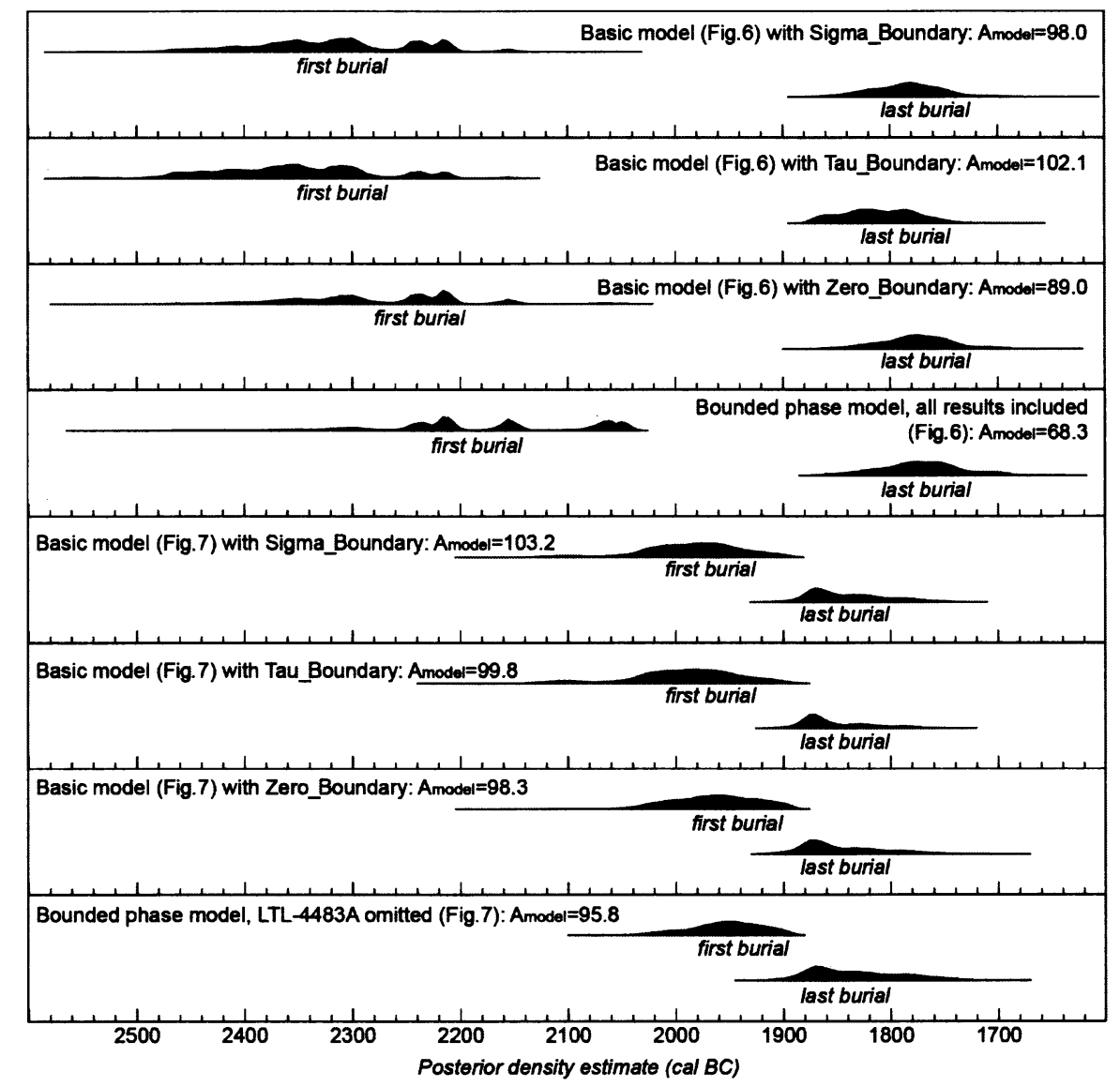

Figure 8 Alternative posterior density estimates for the dates of the First and Last burials at Arano. The variant models are identical to the "bounded phase" models shown in Figures 6 and 7, except that the Boundary Start Arano cemetery has been replaced by Zero_Boundary, Tau_Boundary, or Sigma_Boundary, which incorporate different assumptions about the temporal distribution of the dated events, as discussed in the text and in Bronk Ramsey (2009a).

${ }^{13}$ If LTL-4483A is reliable, the intensity of burial activity may have increased over time, but we cannot realistically use the variant models or the probability distributions of the calibrated dates to determine whether population increased in a linear or exponential fashion - or, in fact, whether G 64 is the only dated representative of an earlier phase of burials, which was followed by a hiatus, and then by a second phase represented by the other 16 dated burials in Settore $B$. 
Alternatively, LTL-4483A may be misleading, either because the sample was contaminated, or due to dietary reservoir effects, or simply because the measurement is a statistical outlier. Another feature of OxCal v 4.1 is the Outlier_Model function (Bronk Ramsey 2009b), which allows the user to specify the prior probability that any sample is an outlier, and the type, scale, and distribution of potential offsets, and returns a posterior probability that each result fits in its position in a chronological model. Using the basic "bounded phase" model (Figure 6), we have applied different Outlier_Models to better understand the scatter of results at Arano.

Statistical outliers (s-type in OxCal) can arise if the errors in ${ }^{14} \mathrm{C}$ measurements are over-dispersed (not normally distributed). ${ }^{14}$ The default s-type Outlier_Model (as illustrated in Bronk Ramsey $2009 \mathrm{~b}$ ) appears to confirm that only LTL-4483A is an outlier. Arbitrarily altering the values of parameters such as the prior probability that any sample is an outlier, or the scale and distribution of potential offsets, does not improve the fit of LTL-4483A within the basic "bounded phase" model (in all permutations attempted, its posterior probability of being an outlier is above $95 \%$ ). Moreover, application of a s-type Out lier_Model reduces the model's dynamic index of agreement $\left(\mathrm{A}_{\text {model }}\right)$ below the $60 \%$ threshold value (Bronk Ramsey $2009 \mathrm{a}$ ). In other words, if the ${ }^{14} \mathrm{C}$ errors were really over-dispersed, and not normally distributed, we should find more apparent outliers; the consistency of the other human bone results emphasizes the poor fit of LTL-4483A.

Other types of Outlier_Model deal with possible ${ }^{14} \mathrm{C}$ age offsets, whether individual ( $r$-type) or systematic (d-type), and with potential calendar age offsets (t-type) (Bronk Ramsey 2009b). The Figure 6 model already embodies a calendar age offset for the charcoal sample, and the human bones sampled were all found in articulation, and should therefore not be older than the date of burial. Both contamination with acrylic, ${ }^{14} \mathrm{C}$-free consolidants such as Paraloid B-72 or Primal AC33 and dietary reservoir effects would give $r$-type ${ }^{14} \mathrm{C}$ age offsets, toward higher ${ }^{14} \mathrm{C}$ ages. ${ }^{15} \mathrm{In}$ either case, use of a $r$-type Outlier_Model only serves to draw attention to the poor fit of LTL-4483A in the "bounded phase" model: allowing small ${ }^{14} \mathrm{C}$ age offsets among the tightly clustered ${ }^{14} \mathrm{C}$ results permits their calendar dates to cluster even more tightly, which reduces the model's dynamic index of agreement below an acceptable level if LTL-4483A is not omitted.

The prior probability of each result being subject to $r$-type offsets would depend on whether diet or contamination is suspected as the cause. Any or all the human bone samples could, in theory, be subject to dietary reservoir effects, which would vary according to individual diet. There is thus no $a$ priori reason to assign different prior probabilities to any human bone result being influenced by dietary reservoir effects, so the same prior probability of being an outlier $(10 \%, 20 \%$, or $50 \%$ in different runs of the model) was assigned to each result. The posterior probabilities obtained were almost always lower than the prior values, except in the case of LTL-4483A, whose posterior probability of being an outlier was always close to $100 \%$. Given the strenuous effort made to avoid sampling consolidated bones, on the other hand, the prior probability of contamination with Paraloid B72 or Primal AC-33 must be low (e.g. 5\%) for the skeletons that were consolidated, and negligible

\footnotetext{
${ }^{14}$ In a set of 18 measurements with normally distributed errors, however, it would not be surprising to find at least 1 result that appears to be an outlier (i.e. that the true ${ }^{14} \mathrm{C}$ age of the sample should be more than $2 \sigma$ higher or lower than the reported result), so we would expect at least 1 result to have an $\mathrm{OxCal}$ individual index of agreement below the critical value of 60 (Bronk Ramsey 1995).

${ }^{15}$ OxCal's default $r$-type model specification (Bronk Ramsey 2009b) therefore has to be altered to only allow positive offsets-for example, by replacing the default $D_{1}$ prior $[\mathrm{N}(0,100)$ : a normal distribution with a mean of 0$]$ with a positive uniform distribution [e.g. U(0,1)].
} 
for those which were not. The posterior probabilities obtained were all $1-2 \%$, except for LTL$4483 \mathrm{~A}$, whose posterior probability of being an outlier reached $100 \% .{ }^{16}$

The Outlier_Model function therefore helps to identify which results do not fit a particular model, but it does not explain why any result might be an outlier or misfit; the rejection of individual results should still be based on archaeological and scientific data. If a large proportion of results are potential outliers or misfits (e.g. if only human bones have been dated, and all may be subject to dietary reservoir effects), then "model averaging" (Bronk Ramsey 2009b) may produce a tighter chronology than if Outlier_Model is not used, which highlights the poor fit of outlying results. Unless there is a priori information that would indicate that ${ }^{14} \mathrm{C}$ age offsets are widespread (e.g. direct evidence of fish consumption), it is probably safer to only use Outlier_Model to identify misfitting results, which may then be omitted from the preferred chronological model.

In summary, it appears that $\mathrm{G} 64$ is exceptional-either because it represents a significantly earlier burial than the other 16 dated burials in Settore $B$, or because this individual had a very different diet to the other dated individuals, or due to some undetected problem with the ${ }^{14} \mathrm{C}$ result, most likely due to unexpected contamination with a consolidant. Although we favor the last explanation, we are unable (on the basis of the ${ }^{14} \mathrm{C}$ results) to rule out any of the others. ${ }^{17}$ Rather than proposing an interpretation that relies heavily on 1 result (suggesting e.g. an exponential increase in population), we conclude that it is preferable to omit LTL-4483A, and that the basic "bounded phase" model (Figure 7) is the most realistic interpretation of the remaining results.

The ${ }^{14} \mathrm{C}$ program aimed to date the start and end of burial activity at Arano, and to estimate its duration; to date 2 graves ( $\mathrm{G} 21$ and G 60) with metal objects; and to detect any spatial-temporal patterning in the use of the cemetery. Under the model shown in Figure 7, disregarding G 64, burial activity at Arano began in $2040-1890 \mathrm{cal} \mathrm{BC}$ or $1990-1910 \mathrm{cal} B C(95 \%$ or $68 \%$ probability; Figure 7 : Boundary Start Arano cemetery), ended in 1910-1730 cal BC or $1900-1800 \mathrm{cal} \mathrm{BC} \mathrm{(95 \%} \mathrm{or} 68 \%$ probability; Figure 7: Boundary End Arano cemetery), and lasted for 0-240 yr or 20-160 yr (95\% or $67 \%$ probability; Figure 9$)$. The young man in $\mathrm{G} 21$ was buried in $1980-1780$ cal BC (95\% probability; Figure 7: G 21 LTL-4480A), and the adult female in G 60 was buried in 2010-1810 cal BC (95\% probability; Figure 7: G 60 LTL-4937A).

The tight clustering of posterior density estimates in Figure 7 means that spatial-temporal patterns within the cemetery (i.e. spatial patterning in the burial dates, listed in Table 4) cannot be proven. Under this model, however, burials $\mathrm{G} 30, \mathrm{G} 32, \mathrm{G} 40, \mathrm{G} 52$, and $\mathrm{G} 60$ each have a posterior probability $>76 \%$ of predating 1890 cal BC, whereas G $3 b, G 44, G 62, G 66$, and G 68 each have a posterior probability $>72 \%$ of postdating $1890 \mathrm{cal} \mathrm{BC}$. The site plan (Figure 2 ) shows that the potentially earlier and later burials occupy roughly the same areas of the cemetery.

\footnotetext{
${ }^{16}$ As each bone sampled was either contaminated or not contaminated, a binary division of posterior probabilities is intuitively appealing. We may contrast this situation with one in which several consolidated bones are dated, and an Outlier_Model is used to gauge the effectiveness of procedures for removing consolidants - in which case the degree of contamination should vary between samples (a situation analogous to dietary reservoir effects).

${ }^{17}$ Stable isotope measurements (undertaken in 2010 at the Dorothy Garrod Laboratory for Isotopic Analysis, University of Cambridge, UK) on collagen from 54 of the 73 inhumations at Arano, including $12{ }^{14} \mathrm{C}$-dated skeletons (including G 64), show little, if any, variation in diet between individuals, and are typical of consumers in wholly terrestrial foodchains (A Varalli, personal communication, 2012). These data indicate that dietary reservoir effects probably do not account for the anomalously old ${ }^{14} \mathrm{C}$ age of $\mathrm{G} 64$.
} 


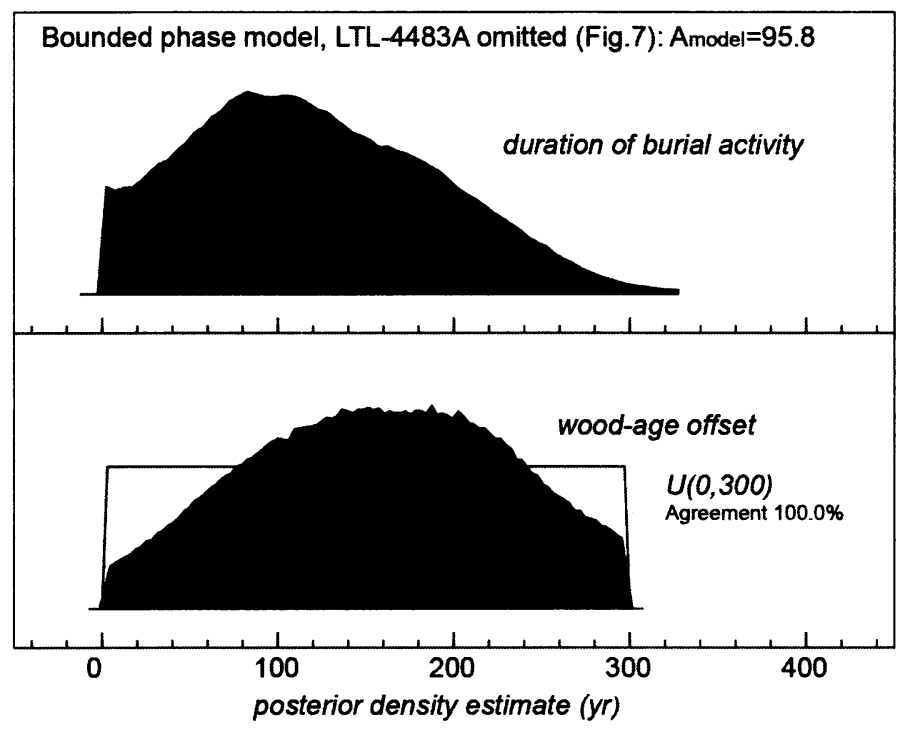

Figure 9 Posterior density estimates of (above) the Span of the "bounded phase" and (below) the intrinsic age of the charcoal sample from G US 20-1a in Settore $A$, assuming that this burial dates to the same phase of burial activity as the cemetery in Settore B. Both estimates were derived from the model shown in Figure 7.

\section{DISCUSSION}

The ${ }^{14} \mathrm{C}$ dating program has confirmed the impression, based on the orderly layout of graves and the minimal variation in funerary practice, that the burial activity at the Arano Settore $B$ cemetery represents a relatively brief period, of probably less than 2 centuries and feasibly less than 1 century (Figure 9: duration of burial activity). The relatively brief use of the cemetery prevents recognition of spatial-temporal patterns in the burial dates. Imprecision in the estimated duration of burial activity (Figure 9) also precludes any discussion of the frequency of burials, and thus of the size of the community using the cemetery.

Based on the posterior density estimate (at $95 \%$ probability) for the start of burial activity (2040 $1890 \mathrm{cal} \mathrm{BC}$; Figure 7: Boundary Start Arano cemetery), it cannot be excluded that the first interments at Arano were made in the very late EBA I A of the north Italian Bronze Age chronology ${ }^{18}$ (the north Italian EBA I A being dated between about the 22nd and the very beginning of the 20th centuries cal BC [de Marinis 1999:25, 28, 33, Figure 8; de Marinis et al., forthcoming]). In fact, a number of ${ }^{14} \mathrm{C}$-dated burials at Arano could, in theory, belong to such a (potential) very late EBA I A phase of burial activity (see the modeled ranges for LTL-4936A [G 52], -4933A [G 32], -4934A [G 40], -5531A [G 30], and -4937A [G 60] in Table 4). The existence of such a potential phase cannot be either corroborated or disproven by the typology of the grave goods, which remains neutral in this respect. The main use of the Arano Settore $B$ cemetery can, however, confidently be placed within the EBA I B/EBA I C of the north Italian Bronze Age chronology. The date of the isolated burial in Settore A (G US 20-1a) could easily fall within the same period, assuming a significant but

${ }^{18}$ Corresponding to the later $\mathrm{Bz} \mathrm{Ala}$ and the later $\mathrm{Bz} \mathrm{Al}$ of the Danube-Carpathian and the northwestern Alpine chronologies, respectively (see David-Elbiali and David 2009:333, Figure 11). 
realistic wood-age offset of $80-240$ yr (68\% probability; Figure 9: wood-age offset) for the ${ }^{14} \mathrm{C}$ dated charcoal fragment (see the estimated date of G US 20-1a in Table 4).

Dated by dendrochronology respectively to within the 20th and the 19th centuries cal BC (de Marinis 1999:25, 28, 33, Figure 8; de Marinis et al., forthcoming), the north Italian EBA I B and EBA I $\mathrm{C}$ can roughly be synchronized with the $\mathrm{Bz} \mathrm{A} 1 \mathrm{~b}$ and the $\mathrm{Bz} \mathrm{A} 2 \mathrm{a}$ (entwickelte Frühbronzezeit) of the chronology established by David $(1998,2002)$ for the EBA-MBA in the Danube-Carpathian area, and with the $\mathrm{Bz} \mathrm{A} 2 \mathrm{a}$ ancien $(=\mathrm{Bz} \mathrm{A} 2 \mathrm{a}-a ̈ l t e r)$ and the $\mathrm{Bz} \mathrm{A} 2 \mathrm{a}$ récent $(=\mathrm{Bz} \mathrm{A} 2 \mathrm{a}-j u ̈ n g e r)$ (phase évoluée du Bronze ancien) of the revised periodization of the EBA-MBA in the northwestern Alpine area recently proposed by David-Elbiali and David (2009). EBA I B and EBA I C occupational phases have been recognized at some north Italian EBA pile-dwelling settlements, for which dendrochronological dates are available (EBA I B: Lucone-area D, layer D [Polpenazze del Garda, Brescia] and Lavagnone 3 [Desenzano del Garda, Brescia], in the Lake Garda moraine amphitheater. EBA I C: Dossetto di Nogara [Verona] and Canàr di San Pietro Polesine [Castelnovo Bariano, Rovigo], in the Veneto Plain; see de Marinis 2002:9; Griggs et al. 2002; Rapi 2002a:275-80, 2878, 2002b:125-6, 142-3; Baioni et al. 2007:90; for a summary of the dendrochronology of these sites, see Martinelli 2005:439-43, Tables 2-3, 2007:106-10, 117, Table 1).

At present, Arano is the best-dated burial complex of the north Italian EBA as a whole (for a nearcomprehensive list of the fairly scarce ${ }^{14} \mathrm{C}$ dates currently available for EBA burials in northern Italy, see de Marinis 2003:26-7, Figures 21-22, 62-3, Figure 40; Valzolgher and Quarta 2009:91, Table 1, 104-5, Table 4). As already emphasized, there remains a regrettable lack of ${ }^{14} \mathrm{C}$ dates for 2 of the most important north Italian EBA cemeteries (i.e. Sorbara di Asola and Valserà di Gazzo Veronese), with which the Arano cemetery shares a number of traits, with respect to both the burial rite (see above) and the grave goods (see, in particular, Sorbara di Asola, where a range of personal ornaments-including, inter alia, miniature [Honsolgen-type] metal Ösenringe, pierced marine shells [Columbella rustica; Glycymeris sp.], and bone beads-were placed with the deceased [Baioni 2000:85-88, Figures 7-10]). Sorbara di Asola has tentatively been attributed to either the EBA I B or the EBA I C (de Marinis 2003:50), ${ }^{19}$ therefore, to the same (main) phase(s) covered by the burial activity at Arano, whereas Valserà di Gazzo Veronese would appear to be later than Arano, having been mainly assigned to the EBA II (18th-17th centuries cal BC), namely to the final phase of the north Italian EBA (de Marinis 2003:50). ${ }^{20}$

One of the main aims of the ${ }^{14} \mathrm{C}$ program at Arano was to establish a secure absolute dating for the metal dagger and neckring associated with $\mathrm{G} 21$ and G 60 (see above), with respect to their remarkable chemical composition. The chemical composition (major and trace element concentrations) of these metal artifacts has been determined by energy-dispersive X-ray fluorescence (EDXRF) spectrometry on drill samples (Pernicka and Salzani 2011:89). The EDXRF analyses, performed in 2008 by Ernst Pernicka at the Curt-Engelhorn-Zentrum Archäometrie (CEZA) gGmbH, Mannheim (Germany), have shown that both the dagger and the neckring are made of Fahlerz (fahlore) copper containing significant levels of antimony ( $\mathrm{Sb})$ and nickel $(\mathrm{Ni})$, as well as arsenic (As) and silver ( $\mathrm{Ag})$ hence, with a composition similar to that of the so-called Singener Kupfer (Singen copper) (also

\footnotetext{
${ }^{19}$ However, Baioni (2000:71) suggested a placement of Sorbara di Asola within the early/middle phases of the EBA ("momento iniziale/centrale del Bronzo Antico"), seemingly corresponding to de Marinis' (1999) EBA I A/EBA I B, to judge from the synchronizations proposed for the cemetery by the author, in particular Lavagnone 2 (EBA I A) and Lavagnone 3 (EBA I B). An assignment of Sorbara di Asola to the early phase of the EBA (David-Elbiali and David's [2009] Bz Al = de Marinis' [1999] EBA I A) has recently been put forward by David-Elbiali $(2011: 195,200)$.

${ }^{20} \mathrm{~A}$ slightly earlier phase of burial activity at Valserà di Gazzo Veronese would seem to be hinted at by the globular, 'S'-profiled pot associated with G 27, likely dating to the EBA I C (de Marinis 2003:47).
} 
known as Singener Metall [Singen metal]) (see Waterbolk and Butler 1965; Krause 1988:183-4, 2003:89-90, Figures 39-40, 122, 157-60; Liversage 1994:65-6; Krause and Pernicka 1998:192, 194-8, Figure 6; Kienlin and Stöllner 2009; Kienlin 2010:134, 173-190). The concentrations of these elements in the 2 Arano metal artifacts are as follows: $\mathrm{Sb}=<1.840 \%$ (dagger) $/ 1.360 \%$ (neckring); $\mathrm{Ni}=2.190 \%$ (dagger) $/ 1.200 \%$ (neckring); As $=0.490 \%$ (dagger) $/ 0.450 \%$ (neckring); $\mathrm{Ag}=$ 0.720\% (dagger) / 1.160\% (neckring) (Pernicka and Salzani 2011:94-5, Table 3; Salzani 2011:83, Table 3, 87, Table 4).

To date, the Arano dagger and neckring are-along with the flanged axe of Torbole type from the (EBA I A) Lavagnone 2 pile-dwelling (Desenzano del Garda, Brescia) (de Marinis et al. 1996:260 1, Figure 2.6, 269, endnote 3; de Marinis 2005:252, Attachment 2 [analysis nr: Te 27]) - the only (published) Fahlerz objects from closed and securely absolutely dated contexts in northern Italy. ${ }^{21}$ As previously seen, Bayesian modeling places G 21 (accompanied by the dagger) and G 60 (accompanied by the neckring) at 1980-1780 cal BC (95\% probability; Figure 7: G 21 LTL-4480A) and at 2010-1810 cal BC (95\% probability; Figure 7: G 60 LTL-4937A), respectively. Prior to the absolute dating of these 2 closed contexts, it was assumed that in northern Italy the use of Fahlerz, Singenlike metal-largely attested in the Polada culture area-was restricted to the earlier phase of the EBA (i.e. to the EBA I A), and that Fahlerz metal was replaced by the copper-tin alloys (i.e. tin bronze) in the ensuing EBA I B (see e.g. de Marinis 2005:253-6, 2006b:250 [unnumbered table], 2011:127-8). ${ }^{22}$ In light of the results from these graves (particularly that from G 21), it is now possible to state that, unless the dagger and the neckring were heirlooms, Fahlerz objects continued to be manufactured at least as late as the EBA I B, and therefore to reasonably postulate an overlap in the use of Fahlerz metal and of the copper-tin alloys in the early 2 nd millennium cal BC.

\section{CONCLUSION}

A firm absolute ${ }^{14} \mathrm{C}$ chronology has been established-using a formal, quantitative Bayesian approach-for the cemetery at Arano, the largest, and by far the most important, EBA burial complex yet discovered in northern Italy. The results of our analysis indicate that burial activity at Arano mainly took place within the 20th-19th centuries cal BC--that is, mainly within the central phases of the north Italian EBA (EBA I B/EBA I C) - and point to a relatively short timespan of use of the cemetery. In addition, the chronological investigation undertaken at Arano has provided noteworthy results regarding the issue of the duration of the production of Fahlerz artifacts in northern Italy in the EBA. Based on the Arano results, the currency of such metal production, hitherto considered to be restricted to the EBA I A, can now also be extended, with a reasonable degree of confidence, to the EBA I B (at least). Furthermore, the accurate absolute dating obtained for the Arano cemetery, combined with other lines of evidence, will help to establish, on a more reliable and sounder basis, correlations between the cemetery itself and other EBA contexts, not only in northern Italy but also in more distant regions (e.g. north of the Alps).

\footnotetext{
${ }^{21}$ It is worth noting here that the chemical composition of the (currently missing) antler-hilted triangular dagger from the Lavagnone 2 pile-dwelling, described in de Marinis (1999:28) as being made of Fahlerz metal, was not actually determined (R C de Marinis, personal communication, 2012).

${ }^{22}$ However, in de Marinis (2000:226), Fahlerz metal is said to have been used through to $\sim 1950 / 1900$ cal BC, thus even in the EBA I B. For the use of Fahlerz metal in northern Italy in the EBA, see also de Marinis 2001:264-5, 2006a:1290-3, 2006b: 225-6; Salzani 2011:59.
} 


\section{ACKNOWLEDGMENTS}

We wish to gratefully acknowledge the Comune di Illasi (Verona, Italy) for funding the Arano ${ }^{14} \mathrm{C}$ dating program (except for OxA-24137). We thank the staff at CEDAD and ORAU, particularly Gianluca Quarta and Fiona Brock, for their work on the samples dated from Arano, as well as for providing analytical details; Jacopo Moggi Cecchi, Silvia Boccone, and Silvia Bortoluzzi (Università degli Studi di Firenze, Italy) for their help with the human bone sampling, and for providing data from their ongoing anthropological analyses of the human remains from Arano; and Alessandra Varalli (Università degli Studi di Firenze, Italy) and Mary Anne. Tafuri (University of Cambridge, UK) for supplying stable isotope data from their unpublished paleodietary investigation of the human remains from Arano. We also thank Marco Marchesini (Università degli Studi di Ferrara, Italy) and Klaas van der Borg (Universiteit Utrecht, the Netherlands) for information on the charcoals from burial G US 20-1a at Arano and the ${ }^{14} \mathrm{C}$ dating of burial G 10 at Valserà di Gazzo Veronese, respectively; and Daniela Cocchi Genick (Università degli Studi di Verona, Italy) for sharing data from her forthcoming monograph on north Italian Copper Age pottery. We are grateful to Christopher Bronk Ramsey (University of Oxford, UK), Wolfgang David (Kelten Römer Museum Manching, Germany), Mireille David-Elbiali (Université de Genève, Switzerland), Raffaele C de Marinis (Università degli Studi di Milano, Italy), Tobias L Kienlin (Ruhr-Universität Bochum, Germany), Stephan Möslein (Bad Tölz, Germany), and 2 anonymous reviewers for their useful comments and suggestions. Finally, Paola Salzani wishes to express her gratitude to Annaluisa Pedrotti (Università degli Studi di Trento, Italy) and Ernst Pernicka (Eberhard-Karls-Universität Tübingen, and Curt-Engelhorn-Zentrum Archäometrie [CEZA] gGmbH, Mannheim, Germany) for their advice and continuing support toward her $\mathrm{PhD}$ research on the Arano cemetery.

\section{REFERENCES}

Baioni M. 2000. La necropoli dell'antica età del Bronzo di Sorbara (Asola-MN). Quaderni di Archeologia del Mantovano 2:41-90. In Italian.

Baioni M. 2005. The Bronze Age cemetery of SorbaraAsola (Mantua, Italy). In: Le Secrétariat du Congrès, editor. Section 11: L'âge du bronze en Europe et en Méditerranée. Sessions générales et posters/The Bronze Age in Europe and the Mediterranean. General sessions and posters. Actes du XIVème Congrès UISPP, Université de Liège, Belgique/Acts of the XIVth UISPP Congress, University of Liège, Belgium, 2-8 September 2001. BAR International Series 1337. Oxford: Archaeopress. p 201-7.

Baioni M, Bocchio G, Mangani C. 2007. Il Lucone di Polpenazze: storia delle ricerche e nuove prospettive. In: Morandini F, Volonté M, editors. Contributi di archeologia in memoria di Mario Mirabella Roberti. Atti del XVI Convegno Archeologico Benacense (Cavriana, 15-16 October 2005). Annali Benacensi XIIIXIV:83-102. In Italian.

Barfield LH. 1999. Copper Age pottery from the Riparo Valtenesi, Manerba del Garda. In: Preistoria e Protostoria del Trentino-Alto Adige/Südtirol. XXXIII Riunione Scientifica dell'Istituto Italiano di Preistoria e Protostoria in ricordo di Bernardino Bagolini. Sessione 2. Preistoria Alpina 35:55-65.

Barfield LH. 2007. Copper Age pottery. In: Barfield LH, editor. Excavations in the Riparo Valtenesi, Manerba, 1976-1994. Florence: Istituto Italiano di Preistoria e
Protostoria. p 159-216.

Barfield LH, Manning SW, Valzolgher E, Higham TFG. 2010. A wiggle-matched date for the Copper Age cemetery at Manerba del Garda, northern Italy. Radiocarbon 52(2-3):984-1001.

Bayliss A, Bronk Ramsey C, van der Plicht J, Whittle A. 2007. Bradshaw and Bayes: towards a timetable for the Neolithic. Cambridge Archaeological Journal 17(Supplement S1):1-28.

Bernabò Brea M, Miari M, Steffè G. 2010. L'Eneolitico dell'Emilia-Romagna. Paper presented at the XLV Riunione Scientifica dell'Istituto Italiano di Preistoria e Protostoria dedicata a Renato Peroni (Modena, 2631 October 2010). Available at http://www.archeologia.unibo.it/Archeologia/Ricerca/Progetti+e+attivita/ Conv_sem/iipp_2010/xlv_iipp_rel_mer27.htm. Accessed 17 July 2012. In Italian.

Brock F, Higham T, Ditchfield P, Bronk Ramsey C. 2010. Current pretreatment methods for AMS radiocarbon dating at the Oxford Radiocarbon Accelerator Unit (ORAU). Radiocarbon 52(1):103-12.

Bronk Ramsey C. 1995. Radiocarbon calibration and analysis of stratigraphy: the OxCal program. Radiocarbon 37(2):425-30.

Bronk Ramsey C. 2000. Comment on 'The use of Bayesian statistics for ${ }^{14} \mathrm{C}$ dates of chronologically ordered samples: a critical analysis.' Radiocarbon 42(2):199 202.

Bronk Ramsey C. 2009a. Bayesian analysis of radiocar- 
bon dates. Radiocarbon 51(1):337-60.

Bronk Ramsey C. 2009b. Dealing with outliers and offsets in radiocarbon dating. Radiocarbon 51(3):102345.

Bronk Ramsey C, Higham T, Leach P. 2004. Towards high-precision AMS: progress and limitations. Radiocarbon 46(1):17-24.

Bruhn F, Duhr A, Grootes PM, Mintrop A, Nadeau M-J. 2001. Chemical removal of conservation substances by 'Soxhlet'-type extraction. Radiocarbon 43(2A): 229-37.

Buck CE, Cavanagh WG, Litton CD. 1996. Bayesian Approach to Interpreting Archaeological Data. Chichester: Wiley. 402 p.

Calcagnile L, Quarta G, D'Elia M. 2005. High-resolution accelerator-based mass spectrometry: precision, accuracy and background. Applied Radiation and Isotopes 62(4):623-9.

Cambini A. 1967a. Micrografia comparata dei legni del genere Quercus. In: Contributi scientifico-pratici per una migliore conoscenza ed utilizzazione del legno. Volume X, nr 19. Florence: C.N.R. - Istituto Nazionale del Legno. p 7-49. In Italian.

Cambini A. 1967b. Riconoscimento microscopico del legno delle querce italiane. In: Contributi scientificopratici per una migliore conoscenza ed utilizzazione del legno. Volume X, nr 20. Florence: C.N.R. - Istituto Nazionale del Legno. p 53-69. In Italian.

Cocchi Genick D. Forthcoming. Le potenzialità informative delle ceramiche nell'analisi storica. Le forme vascolari dell 'età del rame dell 'Italia settentrionale. Verona: QuiEdit. In Italian.

Coplen TB. 1994. Reporting of stable hydrogen, carbon, and oxygen isotopic abundances. Pure and Applied Chemistry 66(2):273-6.

Cornaggia Castiglioni O. 1971. La Cultura di Remedello. Problematica ed ergologia di una facies dell'Eneolitico Padano. Memorie della Società Italiana di Scienze Naturali e del Museo Civico di Storia Naturale di Milano XX(I). Milan: Società Italiana di Scienze Naturali. $79 \mathrm{p} ; 20$ plates. In Italian.

David W. 1998. Zu früh- und ältermittelbronzezeitlichen Grabfunden in Ostbayern. In: Michálek J, Schmotz K, Zápotocká M, editors. Archäologische Arbeitsgemeinschaft Ostbayern/West- und Südböhmen. Archeologická pracovni skupina východni Bavorsko/západni a jižni Čechy. 7. Treffen (Landau an der Isar, 11-14 June 1997). Resümees der Vorträge. Rahden: Leidorf. p 108-29. In German.

David W. 2002. Studien zu Ornamentik und Datierung der bronzezeitlichen Depotfundgruppe HajdúsámsonApa-Ighiel-Zajta. Bibliotheca Musei Apulensis XVIII. Alba Iulia: Altip. 2 volumes. 911 p. In German.

David-Elbiali M. 2011. À la recherche du guerrier dans les sépultures du Bronze ancien et moyen (2200-1300 av. J.-C.) en Europe centre-occidentale et en Italie du Nord. In: Baray L, Honegger M, Dias-Meirinho M-H, editors. L'armement et l'image du guerrier dans les sociétés anciennes: de l'object à la tombe. Actes de la Table ronde internationale et interdisciplinaire (Sens, 4-5 June 2009). Dijon: Éditions Universitaires de Dijon. p 189-224. In French.

David-Elbiali M, David W. 2009. À la suite de JacquesPierre Millotte, l'actualité des recherches en typologie sur l'âge du Bronze. Le Bronze ancien et le début du Bronze moyen: cadre chronologique et liens culturels entre l'Europe nord-alpine occidentale, le monde danubien et l'Italie du Nord. In: Richard A, Barral P, Daubigney A, Kaenel G, Mordant C, Piningre J-F, editors. L'isthme européen Rhin-Saône-Rhône dans la Protohistoire. Approches nouvelles en hommage à Jacques-Pierre Millotte. Actes du Colloque (Besançon, 16-18 October 2006). Annales Littéraires 860. Besançon: Presses Universitaires de FrancheComté. p 311-40. In French.

D'Elia M, Calcagnile L, Quarta G, Sanapo C, Laudisa M, Toma U, Rizzo A. 2004. Sample preparation and blank values at the AMS radiocarbon facility of the University of Lecce. Nuclear Instruments and Methods in Physics Research B 223-224:278-83.

D'Elia M, Gianfrate G, Quarta G, Giotta L, Giancane G, Calcagnile L. 2007. Evaluation of possible contamination sources in the ${ }^{14} \mathrm{C}$ analysis of bone samples by FTIR spectroscopy. Radiocarbon 49(2):201-10.

de Marinis RC. 1997. The Eneolithic cemetery of Remedello Sotto (BS) and the relative and absolute chronology of the Copper Age in Northern Italy. Notizie Archeologiche Bergomensi 5:33-51.

de Marinis RC. 1999. Towards a relative and absolute chronology of the Bronze Age in Northern Italy. Notizie Archeologiche Bergomensi 7:23-100.

de Marinis RC. 2000. Il Museo Civico Archeologico Giovanni Rambotti. Una introduzione alla preistoria del lago di Garda. Desenzano del Garda: Città di Desenzano del Garda. Assessorato alla Cultura. 255 p. In Italian.

de Marinis RC. 2001. Aspetti della metallurgia dell'antica età del Bronzo in Toscana. In: Preistoria e Protostoria della Toscana. Atti della XXXIV Riunione Scientifica dell'Istituto Italiano di Preistoria e Protostoria dedicata a Antonio Mario Radmilli (Florence, 29 September-2 October 1999). Florence: Istituto Italiano di Preistoria e Protostoria. p 253-80. In Italian.

de Marinis RC. 2002. Il significato delle ricerche archeologiche al Lavagnone. In: de Marinis RC, editor. Studi sull'abitato dell'età del Bronzo del Lavagnone, Desenzano del Garda. Notizie Archeologiche Bergomensi 10:1-17. In Italian.

de Marinis RC. 2003. Riti funerari e problemi di paleodemografia dell'antica età del Bronzo nell'Italia settentrionale. Notizie Archeologiche Bergomensi 11:578. In Italian.

de Marinis RC. 2005. Évolution et variation de la composition chimique des objects en métal aux Âges du Cuivre et du Bronze ancien dans l'Italie septentrionale. In: Ambert $\mathrm{P}$, Vaquer $\mathrm{J}$, editors. La première 
métallurgie en France et dans les pays limitrophes. Actes du Colloque International (Carcassonne, 28-30 September 2002). Mémoire XXXVII. Paris: Société préhistorique française. p 249-64. In French.

de Marinis RC. 2006a. Circolazione del metallo e dei manufatti nell'età del Bronzo dell'Italia settentrionale. In: Materie prime e scambi nella Preistoria italiana. Atti della XXXIX Riunione Scientifica dell'Istituto Italiano di Preistoria e Protostoria nel cinquantenario della fondazione dell'Istituto Italiano di Preistoria e Protostoria (Florence, 25-27 November 2004). Volume III. Florence: Istituto Italiano di Preistoria e Protostoria. p 1289-1317. In Italian.

de Marinis RC. 2006b. Aspetti della metallurgia dell'età del Rame e dell'antica età del Bronzo nella penisola italiana. Rivista di Scienze Preistoriche LVI:211-72. In Italian.

de Marinis RC. 2011. La metallurgia a Sud delle Alpi. In: Marzatico F, Gebhard R, Gleirscher P, editors. Le grandi vie delle civiltà. Relazioni e scambi fra il Mediterraneo e il centro Europa dalla Preistoria alla Romanità. Catalog of an exhibition held at the Castello del Buonconsiglio, monumenti e collezioni provinciali, Trento, 1 July-13 November 2011, and at the Archäologische Staatssammlung München, 16 December 2011-27 May 2012. Trento: Provincia Autonoma di Trento. Castello del Buonconsiglio, monumenti e collezioni provinciali. p 127-35. In Italian.

de Marinis RC, Baioni M, Degasperi N, Mangani C, Seragnoli L. 1996. Nuovi scavi al Lavagnone (Desenzano del Garda-Lonato) e considerazioni sull'antica età del Bronzo nell'Italia settentrionale. In: Cocchi Genick D, editor. L'antica età del bronzo. Atti del Congresso Nazionale (Viareggio, 9-12 January 1995). Florence: Octavo. p 257-71. In Italian.

de Marinis RC, Salzani L, Valzolgher E. Forthcoming. La cronologia assoluta dell'età del Bronzo in area padana e alpina nel quadro generale dell'età del Bronzo in Europa. In: Preistoria e Protostoria dell'Emilia-Romagna. Atti della XLV Riunione Scientifica dell'Istituto Italiano di Preistoria e Protostoria dedicata a Renato Peroni (Modena, 26-31 October 2010). Florence: Istituto Italiano di Preistoria e Protostoria. In Italian.

Drusini AG, Carrara N. 1998-1999. Resti scheletrici umani dell'età del Bronzo dalla località di Valserà di Gazzo Veronese (VR). Padusa XXXIV-XXXV:7783. In Italian.

Ferrari A, Steffè G. 2009. SC 5, SC 6. Fiume Panaro, Canova Formiggini. In: Cardarelli A, Malnati L, editors. Atlante dei Beni Archeologici della Provincia di Modena. Volume III. Collina e Alta Pianura. Tomo 2. Florence: All'Insegna del Giglio. p 190-200. In Italian.

Griggs CB, Kuniholm PI, Newton M. 2002. Lavagnone di Brescia in the Early Bronze Age: dendrochronological report. In: de Marinis RC, editor. Studi sull'abitato dell'età del Bronzo del Lavagnone, Desenzano del Garda. Notizie Archeologiche Bergomensi 10:19-33.
Harding AF. 2000. European Societies in the Bronze Age. Cambridge: Cambridge University Press. 552 p.

Kienlin TL. 2010. Traditions and Transformations: Approaches to Eneolithic (Copper Age) and Bronze Age Metalworking and Society in Eastern Central Europe and the Carpathian Basin. BAR International Series 2184. Oxford: Archaeopress. $405 \mathrm{p}$.

Kienlin TL, Stöllner T. 2009. Singen copper, Alpine settlement and Early Bronze Age mining: Is there a need for elites and strongholds? In: Kienlin TL, Roberts BW, editors. Metals and Societies. Studies in Honour of Barbara S. Ottaway. Universitätsforschungen zur prähistorischen Archäologie 169. Bonn: Habelt. p 67104.

Krause R. 1988. Die endneolithischen und frühbronzezeitlichen Grabfunde auf der Nordstadtterrasse von Singen am Hohentwiel. Forschungen und Berichte zur Vor- und Frühgeschichte in Baden-Württemberg 32. Stuttgart: Theiss. 350 p. In German.

Krause R. 2003. Studien zur kupfer- und frühbronzezeitlichen Metallurgie zwischen Karpatenbecken und Ostsee. Vorgeschichtliche Forschungen 24. Rahden: Leidorf. 338 p. In German.

Krause R, Pernicka E. 1998. Frühbronzezeitliche Kupfersorten im Alpenvorland und ihr archäologischer Kontext. In: Mordant C, Pernot M, Rychner V, editors. L'atelier du bronzier en Europe du XX $X^{e}$ au VIII' siècle avant notre ère. Actes du Colloque International "Bronze'96" (Neuchâtel, 4-5 March 1996; Dijon, 69 March 1996). Tome I (Session de Neuchâtel): Les analyses de composition du métal: leur apport à l'archéologie de l'Âge du Bronze. Paris: Éditions du Comité des travaux historiques et scientifiques et du Centre de recherches sur les techniques gréco-romaines de l'Université de Bourgogne. p 191-202. In German.

Liversage D. 1994. Interpreting composition patterns in ancient bronze: the Carpathian Basin. Acta Archaeologica 65:57-134.

Longhi C. 2010. La ceramica della necropoli dell'età del Rame di Remedello Sotto, Brescia. Rivista di Scienze Preistoriche LX:145-65. In Italian.

Longin R. 1971. New method of collagen extraction for radiocarbon dating. Nature 230(5291):241-2.

Maniatis Y, Ziota Ch. 2011. Systematic ${ }^{14} \mathrm{C}$ dating of a unique Early and Middle Bronze Age cemetery at Xeropigado Koiladas, west Macedonia, Greece. Radiocarbon 53(3):461-78.

Mariotti A. 1983. Atmospheric nitrogen is a reliable standard for natural ${ }^{15} \mathrm{~N}$ abundance measurements. Nature 303(5919):685-7.

Martinelli N. 2005. Dendrocronologia e archeologia: situazione e prospettive della ricerca in Italia. In: Attema P, Nijboer A, Zifferero A, editors. Papers in Italian Archaeology VI: Communities and Settlements from the Neolithic to the Early Medieval Period. Proceedings of the 6th Conference of Italian Archaeology held at the University of Groningen, Groningen Insti- 
tute of Archaeology, the Netherlands, 15-17 April 2003. BAR International Series 1452(I). Oxford: Archaeopress. p 437-48. In Italian.

Martinelli N. 2007. Dendrocronologia delle palafitte dell'area gardesana: situazione delle ricerche e prospettive. In: Morandini F, Volonté M, editors. Contributi di archeologia in memoria di Mario Mirabella Roberti. Atti del XVI Convegno Archeologico Benacense (Cavriana, 15-16 October 2005). Annali Benacensi XIII-XIV:103-20. In Italian.

Neugebauer Ch, Neugebauer J-W. 1997. Franzhausen: das Frühbronzezeitliche Gräberfeld I. Fundberichte aus Österreich. Materialhefte Reihe A. Heft 5/1-2. 2 volumes. Horn: Berger. 1271 p. In German.

Neugebauer J-W. 1991. Die Nekropole F von Gemeinlebarn, Niederösterreich. Untersuchungen zu den Bestattungssitten und zum Grabraub in der ausgehenden Frühbronzezeit in Niederösterreich südlich der Donau zwischen Enns und Wienerwald. RömischGermanische Forschungen 49. Mainz am Rhein: von Zabern. 265 p. In German.

Nicolis F. 2002. La necropoli di Valserà nel quadro delle evidenze funerarie dell'antica età del Bronzo in Italia settentrionale. In: Aspes A, editor. Preistoria veronese. Contributi e aggiornamenti. Memorie del Museo Civico di Storia Naturale di Verona ( $2^{\mathrm{a}}$ serie). Sezione Scienze dell'Uomo 5. Verona: Museo Civico di Storia Naturale di Verona. p 144-5. In Italian.

Nicolis F. 2004. Le evidenze funerarie dell'antica età del Bronzo in Italia settentrionale. In: Besse M, Desideri J, editors. Graves and Funerary Rituals during the Late Neolithic and the Early Bronze Age in Europe $(2700-2000 \mathrm{BC})$. Proceedings of the International Conference held at the Cantonal Archaeological Museum, Sion, Switzerland, 4-7 October 2001. BAR International Series 1284. Oxford: Archaeopress. p 11145. In Italian.

Pernicka E, Salzani P. 2011. Remarks on the analyses and future prospects. In: Aspes A, editor. I bronzi del Garda: valorizzazione delle collezioni di bronzi preistorici di uno dei più importanti centri metallurgici dell'Europa del II millennio a.C. Memorie del Museo Civico di Storia Naturale di Verona ( $2^{\mathrm{a}}$ serie). Sezione Scienze dell'Uomo 11. Verona: Museo Civico di Storia Naturale di Verona. p 89-98.

Quarta G, Calcagnile L, D'Elia M, Rizzo A, Ingravallo E. 2004. AMS radiocarbon dating of "Grotta Cappuccini" in Southern Italy. Nuclear Instruments and Methods in Physics Research B 223-224:705-8.

Rapi M. 2002a. Il Lavagnone di Desenzano del Garda (BS). Contributi della dendrocronologia alla cronologia relativa e assoluta dell'antica età del Bronzo. In: De Angelis V, editor. Sviluppi recenti nella ricerca antichistica. Quaderni di Acme 54. Milan: Cisalpino. p 269-300. In Italian.

Rapi M. 2002b. Lavagnone di Desenzano del Garda
(BS), settore B: la ceramica del Bronzo Antico I. In: de Marinis RC, editor. Studi sull'abitato dell'età del Bronzo del Lavagnone, Desenzano del Garda. Notizie Archeologiche Bergomensi 10:109-85. In Italian.

Reimer PJ, Baillie MGL, Bard E, Bayliss A, Beck JW, Blackwell PG, Bronk Ramsey C, Buck CE, Burr GS, Edwards RL, Friedrich M, Grootes PM, Guilderson TP, Hajdas I, Heaton TJ, Hogg AG, Hughen KA, Kaiser KF, Kromer B, McCormac FG, Manning SW, Reimer RW, Richards DA, Southon JR, Talamo S, Turney CSM, van der Plicht J, Weyhenmeyer CE. 2009. IntCal09 and Marine09 radiocarbon age calibration curves, 0-50,000 years cal BP. Radiocarbon 51(4): 1111-50.

Salzani L. 1998-1999. Sepolture dell'antica età del Bronzo da Valserà di Gazzo Veronese (VR). Padusa XXXIV-XXXV:63-75. In Italian.

Salzani L. 2001. Nuovi rinvenimenti da Valserà di Gazzo Veronese. Padusa XXXVII:69-82. In Italian.

Salzani L, Salzani P. 2008. Storie sepolte. Riti e culti all 'alba del duemila avanti Cristo. Catalog of an exhibition held at the Museo Civico di Storia Naturale di Verona, 25 October 2008-30 June 2009. Verona: Museo Civico di Storia Naturale di Verona; Soprintendenza per i Beni Archeologici del Veneto. 38 p. In Italian.

Salzani P. 2011. I metalli del progetto 'I bronzi del Garda': primi risultati e prospettive future. In: Aspes A, editor. I bronzi del Garda: valorizzazione delle collezioni di bronzi preistorici di uno dei più importanti centri metallurgici dell'Europa del II millennio a.C. Memorie del Museo Civico di Storia Naturale di Verona ( $2^{a}$ serie). Sezione Scienze dell'Uomo 11 . Verona: Museo Civico di Storia Naturale di Verona. p 47-87. In Italian.

Stuiver M, Reimer PJ. 1986. A computer program for radiocarbon age calculation. Radiocarbon 28(2B): 1022-30.

Stuiver M, Reimer PJ. 1993. Extended ${ }^{14} \mathrm{C}$ data base and revised CALIB $3.0{ }^{14} \mathrm{C}$ age calibration program. $\mathrm{Ra}$ diocarbon 35(1):215-30.

Valzolgher E, Quarta G. 2009. Date radiocarboniche AMS dal Riparo di Peri (Dolcé, Verona). Commento e analisi bayesiana. Bollettino del Museo Civico di Storia Naturale di Verona. Geologia Paleontologia Preistoria 33:85-113. In Italian.

van Klinken GJ. 1999. Bone collagen quality indicators for palaeodietary and radiocarbon measurements. Journal of Archaeological Science 26(6):687-95.

Ward GK, Wilson SR. 1978. Procedures for comparing and combining radiocarbon age determinations: a critique. Archaeometry 20(1):19-31.

Waterbolk HT, Butler JJ. 1965. Comments on the use of metallurgical analysis in prehistoric studies. I. A graph method for the grouping and comparison of quantitative spectro-analyses of prehistoric bronzes. Helinium 5:227-51. 